Márton, E., Grabowski, J., Tokarski, A.K., Túnyi, I. 2015: Palaeomagnetic results from the fold and thrust belt of the Western Carpathians: an overview

Geological Society, London, Special Publications 425, http://doi.org/10.1144/SP425.1

\title{
PALAEOMAGNETIC RESULTS FROM THE FOLD-AND-THRUST BELT OF THE WESTERN CARPATHIANS: AN OVERVIEW
}

Emő Márton (1*), Jacek Grabowski (2), Antek K. Tokarski (3), Igor Túnyi (4)

(1) Geological and Geophysical Institute of Hungary, Palaeomagnetic Laboratory, Columbus 17-23, H-1145 Budapest, Hungary.paleo@mfgi.hu

(2) Polish Geological Institute - National Research Institute, Palaeomagnetic Laboratory, Rakowiecka 4, 00-975 Warsaw, Poland. jgra@pgi.gov.pl

(3) Institute of Geological Sciences, Polish Academy of Sciences, Research Centre in Kraków, Senacka 1, 31-002 Kraków, Poland.ndtokars@cyf-kr.edu.pl

(4) Slovak Academy of Sciences, Geophysical Institute, Palaeomagnetic Laboratory, Dúbravská cesta 9, 84528 Bratislava, Slovakia. geoftuny@savba.sk

* corresponding author (e-mail: paleo@mfgi.hu) 


\begin{abstract}
The Western Carpathians are separated into an Outer and Inner Carpathians (both comprising several nappe systems) by the extremely narrow and highly deformed Pieniny Klippen Belt. The main phase of deformation and thrusting took place during the Late Cretaceous in the Inner Carpathians, at the end of Cretaceous-Palaeocene in the Pieniny Klippen Belt and in the Miocene in the Outer Carpathians. In this paper a huge amount of palaeomagnetic results of different qualities available from several nappe stacks and from overstep sequences were reviewed and interpreted in terms of tectonics. The data suggest that all three main units participated in two phases of $\mathrm{CCW}$ rotation starting at $18.5 \mathrm{Ma}$, i.e. the Outer Carpathian nappes in front of the already consolidated Alp-Carpathian-Pannonian block became accreted to the block. Late Cretaceous nappe transport, Neogene uplift of 'core mountains' and possibly oroclinal bending of pre-Oligocene age can account for important differences in preCenozoic palaeomagnetic declinations. Most of them exhibit less or no CCW rotation suggested by the overstep sequences implying pre-Cenozoic $\mathrm{CW}$ rotations of variable angles.
\end{abstract}




\section{Introduction}

The Western Carpathians (Fig. 1 inset) are the northernmost segment of the European Alpides. To the north, they are thrusted over the southern margin of the European Platform (Fig. 1 and 2). To the south, the Western Carpathians s.l. contact the Tisza unit along the MidHungarian Line (Fig. 2) a Cenozoic strike-slip fault zone (for review see Fodor 2006). The Western Carpathians are usually subdivided into the Inner Carpathians which formed during the Mesozoic and, the Outer Carpathians formed during the Cenozoic. The two units are separated by the Pieniny Klippen Belt (PKB), a narrow arcuate structure which was formed during two deformational stages, in the Latest Cretaceous-Palaeocene and in the Miocene, respectively. Some authors (e.g. Plašienka 1995) suggest to subdivide the Inner Carpathians into a Central and an Internal Carpathians which are separated by the Meliata suture (Fig. 2 and 3). The Western Carpathians, north of the Pieniny Klippen Belt (Fig. 1) are composed exclusively of non-metamorphosed rocks showing thin-skinned tectonics, whereas the Inner Carpathians are thick-skin orogens (Picha et al. 2005), composed of basement fragments and sedimentary cover.

The deformation in the Western Carpathians took place between the Late Jurassic and the Miocene, getting younger outwards (Plašienka et al. 1997). The main tectonic features of the Carpathians have been formed largely due to the convergence of the European and African plates and, more specifically as a result of successive closures of three branches of the Tethys oceanic realm resulting in three successive subductions (Froitzheim et al. 2008). The final stage of thrusting in the Western Carpathians was partly concomitant with a lateral, northeast directed material escape from the Eastern Alps into the Carpathian-Pannonian realm (Nemčok et al. 1998 and references therein).

Products of volcanism related to the youngest Cenozoic subduction cut and cover the Inner Carpathians, the Pieniny Klippen Belt and the inner part of the Outer Carpathians (Fig. 1a). Intramontane basins are filled with Neogene sediments in the Outer Carpathians whereas Upper Cretaceous, Palaeogene and Neogene sediments occur in the Inner Carpathians.

Palaeomagnetic investigations in the Western Carpathians s.s. started in the 1960s. The first rocks studied were the Lower Permian red shales in the Central Western Carpathians of Slovakia (Kotásek \& Krs 1965) and Neogene andesites in Poland (Birkenmajer \& Nairn 1968). Pioneering studies of Mesozoic sedimentary rocks (Pieniny Klippen Belt, Upper Cretaceous red marls) were published by Bazhenov et al. (1980). In the early phase of 
palaeomagnetic research most of the results were obtained in the former Czechoslovakia (for summary see Krs et al. 1982, 1996).

The Mesozoic sequences in the Central West Carpathians (the Tatra Mts and Slovakian 'core mountains') were first studied by Kądziałko-Hofmokl \& Kruczyk (1987) and Kruczyk et al. (1992). The first publications were followed by several papers by Grabowski (1995, 1997, 2000, 2005; Grabowski et al. 2009, 2010) and by a recent one by Szaniawski et al. (2012). The Triassic sediments of the Silica Nappe, the innermost unit of the Central Carpathians, extending also to the Internal Western Carpathians, were investigated by Márton et al. (1988), Márton et al. (1991), Kruczyk et al. (1998) and Channell et al. (2003). So far the Variscan granitoids of the 'core mountains' were not studied palaeomagnetically, except that of the High Tatra Mts (Grabowski \& Gawęda 1999).

More recently, increased interest in the palaeomagnetism of the Pieniny Klippen Belt resulted in several papers. Systematic palaeomagnetic studies were reported from the Neogene andesites and Upper Cretaceous red marls by Márton et al. (2004, 2013), while Grabowski et al. (2008) and Jelenska et al. (2011) investigated the Jurassic rocks in the Polish and the Slovak sectors of the Pieniny Klippen Belt.

The systematic studies of Cenozoic basins (overstep sequences) in northern Hungary, Slovakia and Poland were carried out by Márton et al. (e. g. 1992, 1996, 1999, 2000, 2007 a, 2007 b), Márton \& Márton (1996) and Túnyi \& Márton (1996), Márton \& Pécskay (1998), Póka et al. 2002, Túnyi et al. 2004, Karátson et al. (2007), Extensive database of palaeomagnetic results from the geographically distributed Tertiary sedimentary rocks of the Outer Carpathian nappes (Magura and Silesian) were presented by Márton et al. (2009 a). A few Mesozoic results were also reported from the Outer West Carpathians. They represent geographically limited areas in the Lower Cretaceous teschenitic rocks in the western part of Silesian Nappe (Krs et al. 1982, Grabowski et al. 2006), in sediments from the western part of the Silesian Nappe and from the Dukla Nappe (Krs et al. 1982), and in red pelagic marls from the eastern sector of Sub-Silesian Nappe (Szaniawski et al. 2013). 


\section{Short geological description of the different units of the Western Carpathians}

\section{Carpathian Foredeep}

The Foredeep of the Western Carpathians is part of an elongated basin extending from Vienna Forest to the Iron Gates on the Danube (Fig. 1, inset). Near Vienna it joins the North Alpine Foreland Basin. The Carpathian Foredeep is filled by Miocene, mostly clastic sediments, up to $3.5 \mathrm{~km}$ thick and, contains a single intercalation of evaporate (Oszczypko et al. 2005) The sediments of the Foredeep basin overly discordantly the southern fringe of European Platform. The contact, where exposed, is sedimentary (Márton et al. 2011 and references therein). In the innermost part of the Foredeep, the Miocene strata are incorporated into the imbricated frontal zone of the Outer Carpathians or form separate tectonic units, composed of northward thrusted slices (Oszczypko et al. 2005, Picha et al. 2005). Outwards, the Miocene strata become sub-horizontal except close to map-scale faults (Márton et al. 2011 and references therein). In Eastern Poland, numerous NE-SW and NW-SE trending normal and strike-slip faults, cut the Miocene fill, whereas, strike-slip faults parallel to the Carpathian front are common in the innermost part of the Carpahian Foredeep in the western part (Márton et al. 2011 and references therein).

\section{Outer Western Carpathians}

The Outer Western Carpathians are north-verging, north-convex thrust-and-fold belt thrusted over the Miocene sediments of the Carpathian Foredeep in the north and separated from the Inner Carpathians by the Pieniny Klippen Belt in the south. They comprise the Skole, Subsilesian-Zdanice, Silesian, Dukla and Magura rootless nappes (Fig. 1), composed largely of Lower Cretaceous to Lower Miocene flysch, locally over $10 \mathrm{~km}$ thick (Slaczka et al. 2005).

The nappe pile started to form during the Eocene (Świerczewska \& Tokarski 1998; Nemčok et al. 2006). Later on, the deformation progressed from the hinterland toward the foreland. The regular sequential succession of the forelandward-verging structures is locally disturbed by out-of-sequence thrust sheets. 
In traditional view, the age of the termination of the nappe stacking was getting younger eastward (Márton et al. $2009 \mathrm{a}$, and references therein), from about 14.5 Ma (end of Langhian, according to Mediterranean and mid -Badenian, according to Central Paratethyan stages, for correlation of the Mediterranean and Central Paratethyan stages, see Rögl, 1996) at the westernmost part, until about $12 \mathrm{Ma}$ (Serravalian, according to Mediterranean and Sarmatian, according to Central Paratethyan stages) at the easternmost part. It was recently discovered, however, that younger than 11.5 Ma (Tortonian, according to Mediterranean and Sarmatian-Pannonian boundary, according to Central Paratethyan stages) old strata are overthrusted by the Outer Carpathian nappes in the western segment (Wójcik \& Jugowiec 1998) which implies that the final episode of thrusting affecting possibly the whole Outer Carpathians, must have occurred after 11.5 Ma.

The nappe stacking took place in two successive stages during which tectonic transport was directed (in present co-ordinates) towards the NW and towards the NE, respectively (Aleksandrowski 1985). During the second stage, the first stage folds were partly refolded and overprinted by folds of second generation (Aleksandrowski 1985), whereas, some of the NE-striking thrusts of the first shortening event were reactivated as sinistral strike-slip faults (Fodor et al. 1995, Decker et al. 1997).

The thrusting in the Outer Carpathians was followed by regional collapse resulting in the formation of intermontane depressions filled by Neogene and Quaternary sediments (Zuchiewicz et al. 2002; Zattin et al. 2011). Some of the faults and thrusts formed during the nappe stacking and subsequent collapse were reactivated during Quaternary time (Tokarski et al. 2007).

In plate tectonic terms, the Outer Carpathians are a Tertiary accretionary complex with the backstop located at the Pieniny Klippen Belt. The accretionary complex was related to the southward subduction of the oceanic or suboceanic crust, intervening between the continental crust of the European plate and the continental crust of the Inner Carpathians and their subsequent collision (e.g. Tomek \& Hall 1993). This process resulted in considerable shortening. The minimum amount of the shortening was calculated by traditional methods as 60-100 km (Książkiewicz 1977; Oszczypko \& Ślączka 1985) and, by restoration of balanced cross-sections as $160 \mathrm{~km}$ (Picha et al. 2005) to $507 \mathrm{~km}$ (Gagała et al. 2012).

Most of the palaeogeographic reconstructions show the pre-folding shapes of the Magura and Silesian basins as north convex, similar to the present-day shapes of the Magura and Silesian Nappes (Książkiewicz 1960; Nemčok et al. 2000 and references therein; Oszczypko \& Oszczypko-Cloves 2006 and references therein). However, in some 
reconstructions (e.g. Picha et al. 2005) both basins are depicted as rectilinear until late Oligocene times. However, no argumets on the shapes of the basins have been presented in any of the above papers. According to Mastella \& Konon (2002) the present-day shape of the Silesian Nappe results from tectonic bending and Nemčok et al. (2006) suggest that the Magura Nappe radically changed its shape since late Oligocene.

Numerous small-scale andesite intrusions of Miocene age cut the inner part of the Magura Nappe (Birkenmajer \& Pécskay 2000 and references therein; Picha et al. 2005 and references therein). Furthermore, numerous small-scale Lower Creaceous hypabyssal intrusions and lava flows of alkaline lamprophyres (Teschenite Association Rocks) occur in the western part of the Silesian Nappe (Lucinska-Anczkiewicz et al. 2002; Grabowski et al. 2003).

Pieniny Klippen Belt (PKB)

The PKB (Figs.1-3) is a narrow, steeply dipping zone of extreme shortening and wrenching (Birkenmajer 1986). It mainly involves Jurassic and Cretaceous sediments with extremely variable lithology and intricate internal structures. Numerous lithostratigraphic and tectonic units of distant provenances were recognized in the Pieniny Klippen Belt, suffering excessive shortening and dispersal within this restricted zone. In general, two types of rock units are distinguished in the belt. The "klippen" which are rigid blocks of Jurassic - Lower Cretaceous limestones. They are embedded in an incompetent matrix, the "klippen mantle", composed of Upper Cretaceous to Palaeogene marlstones, claystones and flysch (Birkenmajer 1986; Plašienka 2012 a). The structure results from two successive deformation stages, a Late Cretaceous - Palaeogene one when the nappe stack was formed and a Miocene deformation stage, when it was strongly modified and almost entirely disintegrated by left lateral strikeslip movements, sub-parallel to the PKB trend (Birkenmajer, 1986; Plašienka, 2012 a). The two deformation stages resulted in the "block-in-matrix" structure of the PKB. Despite the complicated tectonic history, the rocks of the PKB show very little, if any macroscopically observable, ductile strain. 


\section{Inner Western Carpathians}

The Inner Western Carpathians are built up of numerous horst blocks (core mountains) separated by intramontane basins and embayments of the Pannonian Basin System. They comprise several stacks of nappes composed of metamorphic and plutonic Palaeozoic basement and of non or moderately metamorphosed Permian to Cretaceous sedimentary cover (Fig. 2). All nappe stacks are north-verging in the Central Western Carpathians. South of the inferred Meliata suture, in the Internal Western Carpathians, the nappes verge to the south The Central Carpathians comprise six nappe-stacks. These are (from S-N): Silicic, Gemeric, Hronic, Veporic, Fatric and Tatric nappe stack. Thick-skinned stacks which comprise both basement and cover are the Tatric, Veporic and Gemeric stacks. Detached cover nappe stacks are the Fatric, Hronic and Silicic stacks, containing Late Palaeozoic to Mesozoic sedimentary rocks with rare volcanics (Froitzheim et al. 2008 and references therein). The Central Carpathians show a distinct progradation of Mesozoic shortening and collision events from the south towards the north (in present day coordinates) from Late Jurassic to Late Cretaceous times (Plašienka et al. 1997, Picha et al. 2005 and references therein; Froitzheim et al. 2008) related to successive closures of the Meliata and Vahic oceans (Plasienka et al. 1997).

Slivers of oceanic sediments and dismembered ophiolites occur in the in the Meliata suture. South of this suture non-metamorphosed or slightly metamorphosed Palaeozoic and Mesozoic sediments are found in the south- verging Silica Nappe as well as in the different nappe units of the Bükk belt. In the Transdanubian belt the thick Permian - Cretaceous cover complex of a quite simple structure forms the basement, which is a huge SW-NE trending synform (Plašienka et al. 1997).

\section{Overstep sequences}

The basement units are discordantly covered by Upper Cretaceous and younger sediments and volcanic rocks filling intramontane depressions and embayements of the Pannonian basin system (Frotzheim et al. 2008 and references therein). Except for the Upper Cretaceous Gosau facies, the sediments filling the intramontane basins and the Pannonian basin system are unfolded or deformed by open folds. 


\section{Permian and Mesozoic palaeomagnetic results}

Database for all Palaeozoic and Mesozoic results is presented in the Table 1. Most (but not all) palaeodeclinations are located on the geological maps in Figs 3 and 4. Some data were omitted in the areas where lot of results are available (this concerns especially the area of Tatra Mts. and Silica unit).

\section{Križna unit (Fatricum)}

The most numerous pre-Cenozoic data come from the Križna Nappe of Tatra Mts in Poland. The first palaeomagnetic results were presented by Kądziałko-Hofmokl \& Kruczyk (1987). The characteristic direction, obtained from Bathonian to Kimmeridgian radiolarian and nodular limestones ( 1 in the Table 1$)$ did not differ significantly between particular stages, with mean value of pre-folding component close to the expected Eurasian reference direction for the middle - late Jurassic. The shortcomings of the above paper were, that they did not discuss either the problem of remagnetization or the effect of tectonic correction. In the early 1980s the phenomena of remagnetization was not as well known (see McCabe \& Elmore 1989) as today. The almost exclusively normal polarity of magnetization (except one site) was in accordance with the concept of 'Jurassic Quiet Zone' - a long normal interval embracing Callovian - Lower Kimmeridgian (Tominaga et al. 2008 and references therein). A discovery of frequent magnetic reversals in the Late Jurassic (see Opdyke \& Channell 1996; Gradstein et al. 2012 for review) caused that the interpretation of data of KaqdziałkoHofmokl \& Kruczyk (1987) became not straightforward. The above mentioned Oxfordian radiolarian limestones, were re-studied by Grabowski (1995) (2 in the Table 1). It appeared that clustering of characteristic magnetizations, identical as those of Kądziałko-Hofmokl \& Kruczyk (1987) is indeed better after tectonic correction, but their primary origin was questioned: it appeared that other components with higher unblocking temperatures and mixed polarity are better candidates for primary magnetizations. The age of remagnetization was interpreted as Late Cretaceous, since it was definitely older than the final emplacement of the Križna Nappe over the High-Tatric (Tatricum) substratum (Grabowski 1995). In fact, Križna Nappe in the Tatra Mts forms a complicated structure consisting of several imbricated units (duplexes), which behaved quite independently during the late Cretaceous thrusting. 
Soon it appeared that the remagnetization is ubiquitous also in the Middle Triassic to Lower Cretaceous rocks of the Križna Nappe (3 and 4 in the Table 1, Fig. 4). Data collected from many localities situated in several duplex structures proved that the remagnetization was acquired during early phases of thrusting (Grabowski 2000). It must have occurred during the Cretaceous Quiet Zone, before the Coniacian (termination of thrusting in the Central Western Carpathians). Nevertheless, primary magnetization was documented in the calpionellidbearing upper Tithonian - Berriasian limestones ( 5 in the Table 1, Fig. 3 and 4) of the Križna Nappe by Grabowski (2005) and the rocks yielded valuable magnetostratigraphic results (Grabowski \& Pszczółkowski 2006). The calculated Lower to Middle Berriasian palaeopole is indeed located close to the coeval Eurasian data (Galbrun 1985), implying a net postBerriasian clockwise rotation by amount of $15-20^{\circ}$.

The Jurassic pelagic carbonates of the Križna Nappe were also studied by Kruczyk et al. (1992) in several geographically distributed localities in Slovakia: Mala Fatra, Nizke Tatra Mts, Belanske Tatra Mts, Magura Spišska and Choč Mts $(6,9,10,11$, and 12 in the Table 1, Fig. 3 and 4). The characteristic remanences, of exclusively normal polarity were interpreted as of pre-folding age, with fan-like pattern of palaeodeclinations, coinciding with tectonic vergencies of the studied nappe fragments. The results were interpreted as support of the oroclinal bending model of the Central West Carpathians (Burtman 1988). However the age of bending and tectonic rotations were not constrained in the paper, and the age of magnetization was not clearly discussed. It was subsequently suggested (Grabowski \& Nemčok 1999) that these data also might represent the Cretaceous remagnetizations acquired in the "Cretaceous Quiet Zone". The evidences were: 1. exclusively normal polarity of magnetization from rocks belonging to different parts of the Jurassic and 2. unblocking temperatures $350-450^{\circ} \mathrm{C}$ which are typical for undoubtedly remagnetized carbonates in the Tatra Mts (Grabowski 2000). Additional argument for syntectonic nature of the components is quite a large scatter of "pre-folding" inclinations: from 44 to $63^{\circ}$. This problem was pointed out also by Kruczyk et al. (1992). In fact, an inclination only test (Enkin \& Watson 1996, not performed in the source paper) applied for these data gives negative results. It could be easily explained assuming syntectonic (syn-thrusting) age of magnetization. Despite the suspicion of remagnetization, the data of Kruczyk et al. (1992) yielded useful constraints for the rotation pattern in the Križna Nappe. They were confirmed by subsequent studies of Pruner et al. (1998) in the area of Mala Fatra (7 and 8 in the Table 1, Fig. 4), where slight CCW rotations of the Jurassic rocks were documented. 
Further evidence for Mesozoic remagnetizations in the Križna Nappe was obtained from the high resolution study of Strážovce section (Tithonian - Neocomian) in the Strážov Mts (Grabowski et al. 2009). The statistically well defined secondary magnetization (13 in the Table 1) of normal polarity must have been acquired during thrusting episodes in the late Cretaceous. The most plausible tectonic corrections indicate that the rocks must have been magnetized when they dipped opposite to the thrusting direction, forming a hinterlanddipping duplex. The interpretation is concordant with the internal structure of the Križna Nappe, consisting of imbricated units of duplex-type structure (Prokešova et al. 2012). Primary component of double polarity (14 in the Table 1, Fig. 3 and 4,), which was possible to extract from some stratigraphic horizons indicates slight $\mathrm{CCW}$ rotation of similar magnitude as in the Mala Fatra Mts (Kruczyk et al. 1992).

Successful magnetostratigraphic study of the Tithonian - Berriasian limestones was performed by Grabowski et al. (2010) in the Križna Nappe of the Male Karpaty Mts, in the SW termination of the Carpathian arc (15 in the Table 1, Fig. 3). The palaeodeclinations of $300^{\circ}$ account for the largest counterclockwise rotation of Križna Nappe fragment studied so far. The studied sequence was apparently not affected by the syn-thrusting remagnetization of Late Cretaceous age.

\section{Tatricum}

Palaeomagnetic data from the Tatric units are less numerous than from the Križna unit. Firstly, the Tatric rocks represent mostly a shallow water development and are not as suitable palaeomagnetic material as for example Jurassic - Cretaceous pelagic carbonates of the Križna unit. Secondly, during the Alpine orogeny the Tatricum was deeply buried under the overriding Fatric and Hronic units which resulted even in anchimetamorphic conditions in some Central Western Carpathian massifs (e.g. Plašienka 1995). Most of the published palaeomagnetic data were obtained in the High Tatra Mts: 1. the Lower Carboniferous granitoids of the High Tatra Mts (Grabowski \& Gawęda 1999, 16 in the Table 1, Fig. 3 and 4); 2. The Lower Triassic sandstones of the autochthonous sedimentary cover of the Tatricum (Szaniawski et al. 2012, 17 in the Table 1, Fig. 4); 3. Jurassic - Lower Cretaceous limestones (Grabowski 1997) overlying the autochthonous Triassic (18 in the Table 1, Fig. 4,) or included in the overthrusted units (19 in the Table 1). The granitoids and the Mesozoic autochthonous cover rocks reveal consistent $\mathrm{N}$ to $\mathrm{NE}$ palaeodeclinations similar to the 
palaeodeclinations of the Križna Nappe. According to Szaniawski et al. (2012) the Lower Triassic hematite bearing sandstones preserved the primary magnetization while the Jurassic Cretaceous limestones were remagnetized in the Late Cretaceous during the Cretaceous Normal Superchron (Grabowski 1997). One Upper Jurassic locality situated in an allochthonous position (19 in the Table 1) indicates significant CCW rotation in relation to the autochthon. Two localities (20 in the Table 1, Fig. 4) bear evidence of peculiar reversed polarity remagnetizations, residing most probably in pyrrhotite (maximum unblocking temperatures berween 300 and $350^{\circ} \mathrm{C}$ ) which might be interpreted as Cenozoic, acquired before the Neogene tilting event, connected to the uplift of the High Tatra Mts (Grabowski 1997).

Two results are available from the Mesozoic cover of Tatricum outside of the High Tatra Mts, in the Mala and Velka Fatra (Pruner et al. 1998, 21 and 22 in the Table 1, Fig. 3 and 4). Detailed geological setting and tectonic correction is not discussed in the source paper. Mixed polarity in both localities might point to primary magnetization. Slight CCW rotated declinations seem to mirror the trend of rotations described from the Križna Nappe of the Mala Fatra (Table 1, items 6-9) and Strážov Mts (Table 1, item 14).

\section{Choč (Hronicum) and Manin units}

Several geographically distributed localities were studied from the Permian melaphires and red sediments of the Choč Nappe in 1960s and 1970s (23-27 in the Table 1, Fig. 3 and 4) and the results summarized in a review by Krs et al. (1982). The palaeomagnetic vectors were obtained with the technique typical for that time, i.e. the magnetization exhibiting high stability on thermal or AF demagnetization was isolated and statistically evaluated on locality level. Although the within locality scatter is fairly high, the statistical parameters in most cases satisfy the minimum criteria for acceptable palaeomagnetic direction. Field tests for constraining the age of the magnetizations are lacking, but the shallow inclinations are in harmony with expected ones for the Permian. Originally, these results were interpreted in terms of large CW rotations.

The only Mesozoic palaeomagnetic data from the Choč Nappe come from a single locality of Reifling limestones (Middle Triassic), from the Western Tatra Mts in Poland (Grabowski 2000, 28 in the Table 1, Fig. 4). The rock was remagnetized in the Late Cretaceous, the palaeodeclination indicates large clockwise rotation (almost $80^{\circ}$ ) in relation to 
the Tatric autochthon and the Križna Nappe. However, as the remagnetization is of synthrusting age and the exact structural position during the acquisition of the secondary magnetization is not known (it might have dipped even $30-40^{\circ}$ to the south - see Grabowski 2000) the amount of vertical axis rotation can not be precisely estimated. The remagnetization might have been synchronous with resetting of the K-Ar ages, indicating 90Ma, of the Middle Triassic tuffites in the same locality (Środon et al. 2006).

Two results from the Manin unit (Pruner et al. 1998, 29-30 in the Table 1, Fig. 3 and 4) indicate slight $\mathrm{CCW}$ rotation, similarly to the Mesozoic palaeodeclinations from Mala Fatra and Strážov Mts. Mixed polarity might indicate primary magnetization in the Butkov locality (30 in the Table 1), however directions before tectonic corrections and fold test results are not presented.

\section{Gemericum}

There is a single Permian palaeomagnetic direction from this unit (Krs et al. 1982, 31 in the Table 1 and Fig. 3 and 4). To this, the same is applicable as for the Permian palomagnetic directions from the Choč Nappe.

\section{Silica unit}

Primary magnetization was documented in the Triassic of Aggtelek Mts (Silica Nappe s.s.) and Rudabanya Mts (Bodva Nappe) in the Northern Hungary (Márton et al. 1988, 32-34 and 41 in the Table 1 and Fig. 4). Palaeomagnetic record in the Slovakian part of the Silica unit is more complex. Independent studies of Middle to Upper Triassic rocks indicate the presence of remagnetization. Its age is interpreted as syn-tectonic in the Late Cretaceous (Márton et al. 1991, 35 in the Table 1 and Fig. 3 and 4) or post-tectonic, acquired in the Oligocene - Miocene (Kruczyk et al. 1998, 36-37 in the Table 1 and Fig. 4). Channell et al. (2003), in their magnetostratigraphic study in Silická Brezová locality, documented a postfolding secondary component (38 in the Table 1). However they were able to isolate also primary component (39 in the Table 1). Both primary and secondary components in Slovakia account for a ca. $40-50^{\circ} \mathrm{CCW}$ rotation. The rotation in the southern part of Silica unit seems slightly larger $\left(65-90^{\circ}\right)$ in relation to present day north. The two palaeomagnetic data from the 
northern periphery of Silica unit (north of Gemeric unit) also indicate net $45^{\circ} \mathrm{CCW}$ rotation (Márton et al. 1991, 40 in the Table 1, Fig. 3 and 4). However differential rotations occur between the particular tectonic sub-units (Muran and Stratena Nappes).

\section{Pieniny Klippen Belt}

The three sites of Callovian - Tithonian limestones from the Czorsztyn unit in the central (Polish segment) of the Pieniny Klippen Belt (Grabowski et al. 2008) reveal a slight rotation in the CCW sense (42 in the Table 1 and Fig. 3 and 4). The mixed polarity magnetization was interpreted as primary. The palaeodeclinations measured in the middle Upper Jurassic limestones of the western Slovak sector of the Pieniny Klippen Belt (Jeleńska et al. 2011) are badly scattered - the authors did not present any model explaining this observation and therefore the results are not included in Table 1. The palaeodeclination from the Tithonian - Berriasian of the western Slovak sector of the Pieniny Klippen Belt reveal very large $\mathrm{CCW}$ rotation (almost $120^{\circ}$ ). As the studied strata are overturned and refolded, it can not be excluded that additional tectonic correction for the plunge of the fold axis should be applied (Houša et al. 1996, 44 in the Table 1, Fig. 3 and 4).

Recently a systematic palaeomagnetic study of the Upper Cretaceous red marls was carried out along the strike of the Pieniny Klippen Belt from Western Slovakia through Poland to Eastern Slovakia (Márton et al. 2013). Remanences of pre-folding age were documented for 11 localities pointing to net $\mathrm{CCW}$ rotation of ca. $50^{\circ}$ in relation to the present day north (45 in the Table 1, Fig. 3 and 4). Differences in palaeodeclinations between particular localities might be interpreted in favour of the secondary bending of the Pieniny Klippen Belt before the Oligocene.

Some palaeomagnetic directions in the Mesozoic rocks of the Pieniny Klippen Belt are Cenozoic overprints. It concerns two Upper Cretaceous localities in the western and eastern Slovak sector, respectively (Márton et al. 2013), with negative within locality fold test and ca. $75^{\circ} \mathrm{CCW}$ rotated declinations (46a and $46 \mathrm{~b}$ in the Table 1, Fig. 3). They correspond quite well with the Oligocene-Early Miocene declinations which are characteristic of the Inner Carpathian Palaeogene. Another evidence of Neogene remagnetization was found in Middle Upper Jurassic rocks in the central segment of the Pieniny Klippen Belt (Grabowski et al. 2008, 43 in the Table 1, Fig. 3 and 4). Although fold test was not conclusive, their direction before tectonic correction (component $\mathrm{C}$ of Grabowski et al. 2008) reveal similar amount of 
CCW rotation as the above directions of postfolding age (Márton et al. 2013). It should be noted that all these overprints are of reversed polarity, similarly to the primary magnetization of the Neogene andesites in the Pieniny Klippen Belt (Márton et al. 2004, 6 in the Table 2, Fig. 4).

\section{Outer Western Carpathians}

Palaeomagnetic results were obtained from the Lower Senonian siliciclastics of the Biele Karpaty (Magura Nappe, Krs et al. 1993, 47 in the Table 1, and Fig. 3). Double polarity of the characteristic direction, which is based on hematite, suggests primary origin of magnetization. However tectonic correction is not discussed in detail. The palaeodeclination suggests ca. $40^{\circ} \mathrm{CCW}$ rotation.

Most Mesozoic data from the Outer Western Carpathians come from the siliciclastic and volcanic rocks of the Silesian Nappe in the NE Moravia (Krs et al. 1982, 1996, 48-51 in the Table 1, Fig. 3). All of them reveal significant CCW rotated declinations, in accordance with the result from Biele Karpaty. The quality of these results is moderate since clustering parameter $\mathrm{k}$ seldom exceeds 10 , characteristic magnetizations are given only in situ, without any tectonic correction and there is no discussion about possible remagnetization. For example, stereograms from the teschenitic rocks (Krs \& Smid 1979) clearly indicate the presence of rotated and non-rotated palaeodeclinations which suggests that some intrusions might carry a secondary magnetization of normal polarity. Inclination-only test, performed for the teschenite localities in Poland (Grabowski et al. 2006, 52-53 in the Table 1, Fig. 3) was not fully positive, indicating that either the rocks were remagnetized during folding and thrusting, or magnetization, although primary, is not synchronous. Indeed radiometric dating of teschenitic rocks gave quite broad spectra of ages, between 149 and $122 \mathrm{Ma}$ (from the $\mathrm{J} / \mathrm{K}$ up to Barremian/Aptian boundary). In two localities (52a and b in the Table 1, Fig. 3), where positive contact and within locality fold tests were performed, almost no rotation is observed. The other localities (53 in the Table 1, Fig. 3) reveal a CCW rotation of magnitude comparable to that in the Czech part of the Silesian Nappe.

Recently, a result from the Upper Cretaceous red marls of the eastern part of SubSilesian Nappe (Szaniawski et al. 2013, 54 in the Table 1) was published. The authors claim that although significantly affected by inclination shallowing, their result accounts for lack of significant rotation in relation to the reference Cretaceous palaeomeridian. 


\section{Cenozoic palaeomagnetic results}

In the Outer Western and in the Central Carpathians the Cenozoic is represented by flysch of Palaeogene and subordinately Lower Miocene age. In the former area the flysch occurs in rootless nappes, while in the latter it forms the autochthonous cover of the basement units.

From the Silesian Nappe of the Outer Western Carpathians mostly Krosno beds (and mostly claystone members) of Oligocene (in the east also Lower Miocene) age were collected from 24 localities, concentrated in the western, central and eastern segments of the nappe, respectively. Using standard laboratory procedure, tectonically interpretable results were obtained for most localities (Fig. 5, light arrows plotted on the Silesian Nappe). In the western and central segments the characteristic magnetizations are of prefolding age (Table 2, items 1a and $1 \mathrm{~b}$ ), In the eastern segment five localities have primary (Table 2, 1c), five post-folding (Table 2, item 1d) remanences, both groups exhibiting CCW rotations of similar angle. The overall mean palaeomagnetic directions from the central and eastern segments show about $60^{\circ}$ CCW rotation, while the palaeodeclination for the western segment is about $80^{\circ}$.

From the Dukla Nappe the earlier published palaeomagnetic results (Table 2, item 3) are poorly documented. Judging from the original paper (Korab et al. 1981) the results of blanket thermal demagnetization at $350^{\circ} \mathrm{C}$, suggesting moderate $\mathrm{CCW}$ rotation were interpreted in terms of tectonics. It is quite possible that this temperature was not high enough to remove completely the possibly present overprint in the red sediments, so the result should be considered as indication for rotation, but the angle remained uncertain. Table 2, item 2 summarizes the recently obtained and so far unpublished results by Márton and Tokarski, which suggests synfolding magnetization of the grey clastic sediments exhibiting CCW rotations (Fig. 5, light arrows in the Dukla Nappe).

From the Magura Nappe of the Outer Western Carpathians, Upper Eocene and Oligocene flysch (fine grained sandstones, siltstones and marls) was studied at 34 geographically distributed localities of which 13 yielded statistically acceptable palaeomagnetic results (Table 2, item 4, Fig. 5, light arrows plotted on the Magura Nappe). On restoring the strata to the horizontal, the statistical parameters of the overall-mean direction became worse, i.e. the remanence is of postfolding/tilting age. Nevertheless, the 
locality mean directions are fairly consistent before tectonic correction and indicate about $60^{\circ}$ CCW rotation with respect to the present N (Márton et al. 2009 a).

From the Central Carpathian Palaeogene basin samples were taken form two subbasins, the Podhale, north of the Tatra Mts and the Levoča, east of it. From the sampled 18 localities 10 could be evaluated from tectonic point of view (Fig. 5, light arrows without numbers in the Central Carpathian Palaeogene Basin). They indicate about $60^{\circ} \mathrm{CCW}$ rotation (Table 2, item 7) with positive fold/tilt test (Márton et al. 1999, 2009 b). It was also documented that the palaeomagnetic directions are current independent, i.e. the generally E$\mathrm{W}$ oriented sedimentary transport could not bias the palaeomagentic directions from that of the ambient Earth magnetic field (Márton et al. 2009 b). Previously published palaeomagnetic directions interpreted as of pre-tilting age for one locality from the eastern part of the Levoča basin (Fig. 5, Table 2, item 11, Túnyi et al. 1996) and from the contact between the Levoča and East Slovak basins (Fig. 5, Table 2, item 12, Márton et al. 2000) and one Upper Cretaceous locality with documented secondary remanence (Fig. 5, Table 2, item 46b, Márton et al, 2013) all exhibited large CCW rotations. Such statement can be also made of the area west of the Central Carpathian Palaeogene basin (Fig. 5, Table 2, items 8, 9 and 10, Túnyi et al. 1996), interpreted as primary remanences, and the posttilting remanence at the western end of the Pieniny Klippen Belt, measured on Upper Cretaceous red marls, (Fig. 5, Table 2, item 46a, Márton et al. 2013).

In the Inner Carpathian area there is another large Palaeogene basin (Fig. 1) from which not only Palaeogene palaeomagnetic results are available, but also younger ones. Three sedimentary Palaeogene localities near the river Danube (Fig. 5, Table 2, items 13-15, Túnyi et al. 1996) and three from the southern margin of the Bükk Mts (Márton \& Márton 1996) indicate large CCW rotation. Similar values were obtained from Upper Eocene andesites and thermally altered contact sediments from the Mátra Mts (Fig. 5, Table 2, item 16), 11 Lower Miocene ignimbrite sites from the Bükk Mts (Fig. 4, Table 2, item 20) as well as from sediments (Fig. 5, Table 2, item 18) and ignimbrites (Fig. 5, Table 2, item 19) of the NógrádNovohrad basin of Northern Hungary (Márton and Márton, 1996) and Southern Slovakia (Márton et al. 1996). The mentioned sediments and volcanic rocks are in autochthonous position above Internal Carpathian basement units (Fig. 1 and 2). At several places, they are covered by Mid-Miocene volcanics and sediments which exhibit only about $30^{\circ} \mathrm{CCW}$ rotation (Fig. 5, 21-23, 25-28), while the Upper Miocene rocks are characterized by slight CW or no rotation with respect to the present North (Table 2, items 24 a-f). As the volcanic horizons are well dated with $\mathrm{K} / \mathrm{Ar}$, and most sediments with biostratigraphic method, the age 
of the rotations are fairly well-constrained in the area of the Inner Carpathian Palaeogene basin. The significance of this age control for the Cenozoic displacements will be discussed later.

The East Slovak basin is separated from the rest of the Pannonian basin by a volcanic chain of the Tokaj-Slanec Mts. In this area, including the Vihorlatské Mts, CCW rotated palaeomagnetic directions characterize most of the magmatic rocks (Table 2, items 31-33) suggesting that here the rotation was younger than in the Central and Internal Carpathian Palaeogene basins.

\section{Discussion and tectonic interpretations of the palaeomagnetic results}

\section{Cenozoic results}

The Cenozoic palaeomagnetic results from the Western Carpathians represent overstep sequences for the Inner Carpathians, while in the Outer Carpathians the studied Palaeogene sediments were folded and thrusted until the Miocene. Despite of the different tectonic settings, there is a remarkable consistency within and between the two areas in palaeomagnetic declinations measured on Palaeogene rocks, indicating large $\mathrm{CCW}$ rotation (Fig. 6). As documented in the original papers, the results were obtained using modern laboratory procedures and evaluation. Before tilt corrections, the directions of the characteristic remanences were typically far from that of the present Earth's magnetic field at the sampling areas, proving long term stability. According to between locality fold/tilt tests and reversal tests (where applicable) the characteristic remanences are primary or of synfolding age. In the latter case, the acquisition time is quite close to the time of deposition. The Magura Nappe (Table 2, item 4) and a population of localities in the eastern segment of the Silesian Nappe (Table 2, item 4d) are notable exceptions. However, the magnetizations of post-folding age are regionally consistent in both areas, therefore valuable in tectonic interpretation. The results summarized in Table 2 and shown in Fig. 7a-c, suggest that during the Miocene, the Inner Carpathians (an already consolidated block) accreted the sediments of the Outer Carpathians. Relative rotations within and between nappes seem to be within the resolution of the palaeomagnetic data. Some differences in declinations within the central segment of the Silesian Nappe and in the Dukla Nappe can be attributed to post-folding uplift, 
larger average rotation in the western segment in the Silesian Nappe than elsewhere to strikeslip displacements, also postdating the folding (Márton et al. 2009 a).

An interesting aspect of the palaeomagnetic data set is that overall mean palaeomagnetic declinations of the vectors, both of pre and postfolding ages (Table 2, items 1-4, Fig. 7a-c), are practically coincident. It follows that the internal deformation of the nappes must have taken place between the two acquisition times. In the Silesian and Dukla Nappes, where AMS lineations are well defined, there is a good correlation between them and the strikes of the sampled beds (Fig. 8), i.e. the magnetic fabric was imprinted during the compressional regime which prevailed during folding and thrusting of the nappes. Thus, the order of the events which were important from palaeomagnetic and tectonic aspects are the following. (1) Acquisition of the remanent magnetizations of prefolding age, before the Miocene, (2) internal deformation of the nappes, during which remanences of syn-folding age and the AMS lineations were acquired, (3) co-ordinated rotation of the nappes together with the Inner Carpathian block.

The co-ordinated rotation of the Outer and Inner Western Carpathians must have taken place during two time periods, between 18.5-17.5 and between 16.0 -14.5 Ma. The time constraints are coming from the Internal Carpathian (North Hungarian-South Slovakian) Palaeogene basin, where a large number of well dated localities/sites in sedimentary and igneous rocks yielded good palaeomagnetic results (Table 2, and Fig. $7 \mathrm{~d}$ and e). Here, older than 18.5 Ma sediments and igneous rocks exhibit about $60^{\circ} \mathrm{CCW}$ rotation, those between 17.5 and 16.0 Ma about $30^{\circ}$, while younger than $14.5 \mathrm{Ma}$ are characterized by declinations which are close to what is expected in a stable European framework. This means that the final thrusting of the Outer Western Carpathians around 11.5 Ma postdates the process of the docking of the Outer Carpathian nappes by $\mathrm{CCW}$ rotation to the southern margin of the European plate.

By the time the rotations were over in the Internal Carpathian Palaeogene basin, CCW rotation was still in progress in the East Slovak basin (Fig. 7e). The tectonic implication of this results, which is corroborated by those from the Maramures area in Romania (Márton et al. 2007 c) is still to be explored. 
Interpretation of the Mesozoic palaeomagnetic data from the Western Carpathian area poses more problems than Cenozoic. As can be seen from the Fig. 3 and 4, senses and amounts of rotations are varied, even within the same tectonic units. Regional syn-tectonic remagnetizations were documented in several tectonic units (like Silica, Križna and Choč). An additional problem is related to the complexity of the tectonic correction: Mesozoic rocks were deformed during nappe thrusting in the late Cretaceous and the geometry of these EoAlpine structures was definitely modified during the Neogene uplifts of the "core mountains". In order to reconstruct the position of Mesozoic nappe stacks between Late Cretaceous and Neogene a tectonic correction for the overlying Palaeogene rocks is applied which in the Tatra Mts amounts to $10^{\circ}$ (azimuth) $/ 30^{\circ}$ (tilt around horizontal axis) (see e.g. Grabowski 1997; Grabowski et al. 2009; Szaniawski et al. 2012). In fact all secondary magnetizations of inferred syn-thrusting age are of limited value for regional palaeotectonic interpretations, although they appeared to be useful in local tectonic reconstructions (e.g. position of beds during intermediate stages of thrusting - see e.g. Grabowski 2000; Grabowski et al. 2009).

Areas with consistent and partly consistent sense and magnitude of rotations observed on Cenozoic and older rocks

Consistent $\mathrm{CCW}$ rotated palaeodeclinations in both primary and secondary palaeomagnetic components are observed within the Triassic rocks of the Silica unit. The observations are in good agreement with the results from the surrounding Cenozoic basins and indicate that the rotations observed within the Mesozoic rocks of the Silica unit are predominantly of Cenozoic age. The Silica units must have rotated together with the ALCAPA superunit and no significant rotation of Silica took place between the Triassic and Miocene.

Coincidence between the Mesozoic and Cenozoic palaeodeclinations is observed in the Male Karpaty Mts. The detected CCW rotations of the Križna unit and the Palaeogene cover are identical and therefore must be interpreted as Neogene. The same sense of rotation with somewhat larger angle can be inferred for the Permian volcanics of the Choč Nappe, although the almost equatorial inclination permits also alternative interpretation of large $\mathrm{CW}$ rotation of the Choč Nappe in the Male Karpaty. 
Participation of the Pieniny Klippen Belt in the Miocene CCW rotation of the AlpCarpathian-Pannonian superunit is well constrained (Márton et al. 2004, 2013), since the overall-mean primary magnetizatons of the Upper Cretaceous pelagic marls exhibit similar rotation than the oldest group of Cenozoic rocks from the Inner Western Carpathians (Fig. 7a). Thus it might be accepted that PKB units have not rotated significantly between the late Cretaceous (Albian?) and Miocene, except some small scale disturbances that might be attributed to weak oroclinal bending (Márton et al. 2013). The pre-Late Cretaceous data set from the same belt clearly disagrees with the late Cretaceous data. Callovian - Kimmeridgian results from the central part of the Pieniny Klippen Belt (Grabowski et al. 2008) exhibit only weak $\mathrm{CCW}$ rotations. The data might be interpreted in favour of a local(?) $\mathrm{CW}$ rotation of the central part of the belt, between the Late Jurassic and Late Cretaceous. However bearing in mind intensive tectonic reworking of the Pieniny Klippen Belt (e.g. Birkenmajer 1986; Ratschbacher et al. 1993; Nemčok \& Nemčok 1994; Plašienka 2012 a) it can not be excluded that different palaeodeclination trends observed result rather from local tectonic rotations and/or disharmonic tectonic deformations of hard blocks of Upper Jurassic Czorsztyn limestones and relatively more competent Upper Cretaceous marls.

Mesozoic (Krs et al. 1982, 1993, 1996) and Cenozoic (Márton et al. 2009 a) results from the western part of the Outer Western Carpathians indicate generally consistent CCW rotations of both Magura and Silesian Nappes which must have occurred after the Oligocene. Non-rotated Mesozoic palaeodeclinations were reported east of $19^{\circ} \mathrm{E}$ from two localities of the Lower Cretaceous teschenitic rocks of the Silesian Nappe (Grabowski et al. 2006) and the Upper Cretaceous marls of Sub-Silesian Nappe (Szaniawski et al. 2013). At present state of investigations it is too early for their robust tectonic interpretation. The apparent lack of rotations in the Mesozoic of the central part of the Silesian unit (Grabowski et al. 2006) needs confirmation from well bedded sedimentary rocks - secondary nature of magnetization can not be excluded: although both fold and contact tests were positive, a very steep palaeoinclination observed (between 60 and $70^{\circ}$, which corresponds to a latitude ca. $48^{\circ} \mathrm{N}$ ) is hardly acceptable for the Early Cretaceous in the area. Characteristic directions of Szaniawski et al. (2013) although they pass the fold test, need some additional assumption for a proper interpretation, since the inclination is far too shallow for the Late Cretceous and results from more geographically distributed localities are needed to verify the regional significance. 
Areas with non-consistent sense and magnitude of rotations observed on Cenozoic and older rocks

The best documented contrast between Palaeogene and Mesozoic palaeodeclinations occurs in the area of the High Tatra Mts. A difference between palaeodeclinations from the Central Carpathian Palaeogene Basin (Márton et al. 1999; 2009 b) and the Tatric and Fatric sequences (e.g. Kądziałko-Hofmokl \& Kruczyk 1987; Grabowski 2005) amounts to $90^{\circ}$. The logical consequence of those observations is that the area must have rotated clockwise by amount of ca. $90^{\circ}$ between the Late Cretaceous (Turonian?) and Oligocene (Grabowski \& Nemčok 1999; Grabowski 2005). The nature and geographical extent of the areas involved in the rotation remains unclear. Paralellisation of this rotation with that which affected the Northern Calcareous Alps between the Barremian and Danian (Mauritsch \& Márton 1995; Grabowski 2005) is also hypothetical since palaeomagnetic interpretations in the Northern Calcareous Alps have been substantially modified (Pueyo et al. 2007). It is noteworthy that the results from the Tatra Mts were obtained from all major tectonic units: Tatricum (both basement rocks and sedimentary cover), Fatricum and Hronicum. All primary and most secondary Mesozoic directions reveal NNE to E rotated trend of palaeomagnetic declinations. The Neogene uplift most probably did not affect significantly the primary Mesozoic palaeodeclinations (Grabowski 2005; Szaniawski et al. 2012) since the bedding azimuth of the studied Mesozoic beds is very close to those of the Palaeogene cover (see also Piotrowski 1978).

Most palaeomagnetic results from the Mesozoic rocks between the High Tatra and Male Karpaty Mts were obtained from the Križna Nappe. It must be kept in mind that a part of these directions (Kruczyk et al. 1992) most probably represent syn-tectonic remagnetizations and a real structural context of their acquisition is not clear. It seems however, that a trend of increasing $\mathrm{CCW}$ rotations is observed along the strike of the orogen (Grabowski et al. 2010). It is supported by the sporadic results from Tatric and Manin units (Pruner et al. 1998). As a whole, the data might be interpreted as an effect of oroclinal bending (Kruczyk et al. 1992) or radial thrusting. In this case difference between Palaeogene and Mesozoic palaeodeclinations would have decreased SW from the High Tatra Mts. An alternative explanation would be, that the rotations within the Križna Nappe might be related to the different tilting azimuths of different massifs during the Neogene (Szaniawski et al. 2012). Indeed massifs uplifted around a roughly E-W oriented axis (like Tatra, Nizke Tatry or Choč Mts) reveal no rotation or slight $\mathrm{CW}$ rotation, those uplifted around SW-NE axes - 
CCW rotations (Mala Fatra, Strážovske Vrchy and Male Karpaty) while a single locality in the Spišska Magura, located just at the prominent Neogene strike-slip fault (Sperner et al. 2002) - extreme CW rotation. Definite verifications of either models is not possible now and would need further integrated palaeomagnetic and field studies.

Palaeozoic and a single Mesozoic result from the central and eastern part of the Choč unit reveal large rotations. The Palaeozoic results should be verified since the results were obtained in the early days of palaeomagnetism and neither details of demagnetization nor the interpretation of characteristic directions were clearly presented. If we accept the reality of $\mathrm{CW}$ rotated declinations in the Choč Nappe and correct them for effect of the $\mathrm{CCW}$ rotation of entire Alp-Carpathian-Pannonian unit in the Miocene, we have to calculate with a huge CW rotation (ca. $80-130^{\circ}$ ) of the Choc Nappe before Neogene.

Palaeogene - Neogene(?) remagnetizations of the Mesozoic rocks in the Central Western Carpathians and the Pieniny Klippen Belt

Documentation of secondary magnetizations of the Palaeogene or Neogene age in the Mesozoic rocks is very important, since it creates a link between the Mesozoic and Cenozoic kinematics. It was already mentioned that presence of consistent post-folding remagnetizations of reversed polarity and presumed Neogene age was reported from the western, central and eastern sectors of the Pieniny Klippen Belt (Grabowski et al. 2008; Márton et al. 2013).

In the rocks of the Križna Nappe no similar directions have been reported so far. However, reversed polarity magnetizations documented in two localities of the Tatricum unit of the Tatra Mts (component C of Grabowski 1997) might be interpreted as overprints acquired just before the Neogene uplift of the Tatra Mts. Having rotated the Tatra Mts back to its pre-Neogene position (see chapter Mesozoic and Palaeozoic results) the reversed overprints attain a declination of $140^{\circ}$, which is again close to the secondary directions from the Pieniny Klippen Belt mentioned above and primary directions from the Pieniny andesites (Marton et al. 2004). It seems that a persistent reversed polarity remagnetization which might have been coeval with intrusions of the Pieniny andesites (Birkenmajer \& Pécskay 2000), affected also the Mesozoic rocks. Its age might be related with so-called "Mid-Miocene thermal event" which caused resetting of the fission track ages some of the Oligocene rocks in the Podhale Basin (Danišik et al. 2012; Anczkiewicz et al. 2013). 


\section{Mesozoic palaeolatitudes}

It is evident from the Table 1 that only a small amount of the available palaeomagnetic data might be suitable for palaeolatitude estimations. All syntectonic remagnetizations must be excluded since their acquisition took place at different stages of thrusting processes in the Late Cretaceous and the position of beds during acquisition of secondary magnetization is not always possible to reconstruct. It must be stressed that data of Kądziałko-Hofmokl \& Kruczyk (1987) which for a long time has been referred among the reference Middle - Late Jurassic poles for the European Platform as 'Subtatric nappe sediments, Poland' (see e.g. Besse \& Courtillot 1991, 2002, 2003; Van der Voo 1993; Torsvik et al. 2012) must also be included to the group of syn-thrusting remagnetizations. It is supported not only by incomplete demagnetization but also by the new results from the coeval rocks from the Pieniny Klippen Belt. Primary palaeoinclinations of the Middle - Upper Jurassic rocks of the Pieniny Klippen Belt (see below) are significantly shallower than those from the Križna unit (KądziałkoHofmokl \& Kruczyk 1987 - ca. $40^{\circ} \mathrm{N}$ lat.) and the difference is statistically significant. As it is extremely unlikely that the depositional area of the Križna unit was situated north of the Pieniny Klippen Belt (see e.g. Birkenmajer 1986; Plašienka et al. 1997) the secondary nature of the component earlier interpreted as primary, from the Križna Nappe must be accepted.

Despite the need to reject a number of data, the palaeolatitudinal drift history of the Central and Inner West Carpathians together with the Pieniny Klippen Belt, might be roughly constrained (Fig. 9). The Lower Triassic palaeoinclinations obtained from the northern (Szaniawski et al. 2012) and southern periphery of the Inner Western Carpathians (Márton et al. 1988) are quite concordant and account for the palaeogeographic position of the area at palaeolatitude of ca. $11-13^{\circ} \mathrm{N}$. For the rest of the Triassic, results are available from the Silica and Bodva Nappes (Márton et al. 1988; Márton et al. 1991; Channell et al. 2003). They indicate a quick northward drift from ca. $23-25^{\circ} \mathrm{N}$ in the Middle Triassic up to $34^{\circ} \mathrm{N}$ in the Late Triassic. No data exist for the Lower Jurassic. Middle and Upper Jurassic results from the Polish sector of the Pieniny Klippen Belt point to ca. $22^{\circ} \mathrm{N}\left( \pm 5^{\circ}\right)$ latitude in the Callovian - Kimmeridgian (Grabowski et al. 2008). The relatively low palaeolatitudes for the Bajocian $\left(21.7^{\circ} \mathrm{N} \pm 1.5^{\circ}\right)$ and Oxfordian - Kimmeridgian $\left(24.6^{\circ} \mathrm{N} \pm 5.6^{\circ}\right)$ were also reported for the western Slovak sector of the belt by Jeleńska et al. (2011). These observations might be interpreted in favour of a southward drift of the Western Carpathians between the Late 
Triassic and Middle Jurassic. It matches well the model of the southward drift of the Adriatic Plate between the Lower and Middle Jurassic due to an opening of the Liguria - Piedmont ocean (Muttoni et al. 2005, 2013) which continued to NE into the Carpathian realm as Vahic - Magura Ocean (e.g. Plašienka 2012b and references therein). It should be noted that southward drift between the Middle Jurassic (Bajocian - Bathonian) and mid-Oxfordian was documented in the easternmost part of the Pieniny Klippen Belt in Ukraine (Lewandowski et al. 2005), but its timing was apparently slightly later than in the Western Carpathians.

Abundant data from the Berriasian (Houša et al. 1996; Grabowski 2005; Grabowski et al. 2009, 2010) are very consistent and indicate a palaeolatitude of ca. $28^{\circ} \mathrm{N}$ for both the Central Western Carpathians and Pieniny Klippen Belt. The northward drift of both units in the latest Jurassic is again concordant with the similar palaeolatitudinal shift of the Lombardian basin (Muttoni et al. 2005) and Ukrainian part of the Pieniny Klippen Belt (Lewandowski et al. 2005).

The northward drift apparently continued throughout the Cretaceous, similarly to that of the Adriatic Plate (Márton et al. 2010) since the mean Late Cretaceous palaeolatitude of the Pieniny Klippen Belt amounts to $33^{\circ} \mathrm{N}, \pm 10^{\circ}$ (Márton et al. 2013).

The Mesozoic palaeolatitude data for the Outer Western Carpathians are sparse. Very high palaeolatitudes calculated from the Lower Cretaceous teschenitic rocks (ca. $43^{\circ} \mathrm{N}-\mathrm{Krs}$ et al. 1982, 1996; Grabowski et al. 2006) correspond rather to expected Cenozoic values (Besse \& Courtillot 2002, 2003). The mean value for the four studies of the Upper Cretaceous rocks of the Magura and Silesian Nappes (Krs et al. 1982, 1996) is ca. $34^{\circ} \mathrm{N}$ which is not far from the coeval results from the Pieniny Klippen Belt (Márton et al. 2013).

\section{Conclusions}

The present review focused on the tectonic applications of the palaeomagnetic results from the Western Carpathians which are subdivided into an Outer and an Inner Western Carpathian nappe system, separated by a narrow, tectonically complicated zone, the Pieniny Klippen Belt. The Inner Western Carpathians are further subdivided into a Central and an Internal Carpathians which are in contact along the Meliata suture. The nappes of the Outer Western Carpathians are rootless and were emplaced in the Early Miocene. The overstep sequences here are Miocene sediments occurring in isolated basins. The basement of the Inner 
Western Carpathians is built up of several nappe stacks, some thick skinned, consisting basement and cover units, while the others are only cover units. Nappe transport terminated in the Inner Carpathians during Late Cretaceous and the nappes are discordantly covered by latest Cretaceous-Miocene sediments and Neogene igneous rocks. The palaeomagnetic results discussed in this paper represent the above mentioned main units and their analysis lead to the following conclusions:

1. The Internal Western Carpathians are characterized by high diversity of the palaeomagnetic declinations obtained for the basement rocks. The results, interpreted partly as of pre-, partly of syn- and post-folding age suggest important relative rotations during nappe transport, uplift of the 'core mountains' and possibly by oroclinal bending.

2. Overall-mean palaeomagnetic declinations (based on several sites/localities) in the Central Carpathians only slightly depart from the present north in the Tatra Mts, while moderate westerly declinations occur towards the west. Exceptions are the Little Carpathians and the Silica Nappe, where large CCW rotations are documented. Single sites/localities usually indicate large $\mathrm{CW}$ or $\mathrm{CCW}$ rotations. Checking on their quality (basically applicable to Permian results) and their tectonic significance (local anomalies connected to tectonic lines?) is to be explored in the future.

3. Overstep sequences in the Internal Western Carpathians (namely in the Central and Internal Carpathian Palaeogene basins) exhibit large and fairly consistent CCW rotation up to the age of $18.5 \mathrm{Ma}$, which is similar in sense and magnitude to the net post-Late Cretaceous rotation of the Pieniny Klippen belt. These observations prove that the named areas formed a single block during the Miocene. The block rotated first in the CCW sense between 18.5 and 17.5 Ma, then during the interval of 16.0-14.5.

4. The above described Miocene $\mathrm{CCW}$ rotations must have affected the basement of the Internal Western Carpathians. Consequently, the basement areas exhibiting less CCW rotation than the overstep sequences, must have rotated in the $\mathrm{CW}$ sense before the Late Cretaceous.

5. From the Outer Western Carpathians most Cretaceous and all Palaeogene data suggest an overall $\mathrm{CCW}$ rotation. The palaeomagnetic control on the Mesozoic situation is quite poor, but the Palaeogene results are geographically distributed and represent the Magura, the Dukla and the Silesian Nappes. They suggest that the Outer Carpathians rotated in co-ordination with the already consolidated Inner Carpathians and the Pieniny KIlippen belt during the Miocene. The folding of the nappes (also manifested 
in well defined AMS lineations correlating in direction with the strike of the sampled beds) followed the acquisition of the primary magnetizations of the Palaeogene flysch. As the magnetization of post-folding age is aligned with that of the primary, even the first CCW rotation must have been subsequent to the folding events and the Outer Carpathians attained their present orientation only during the Miocene.

\section{Acknowledgment}

We thank Dušan Plašienka for providing and discussing papers about the geological and tectonic development of the Inner Carpathians, Gábor Imre and Jan Turczynowicz for technical assistance. Careful and constructive reviews by two anonymous referees are greatly appreciated. Financial support from the Hungarian Scientific Research Fund (OTKA, Project number K105245), from Polish-Hungarian bilateral Scientific and Technological project 2011-2012 and from a joint project of the Academies of Science of Poland and Hungary (2011-2013) is acknowledged. 


\section{References}

AleKsANDrowsKi, P. 1985. Structure of the Mt. Babia Góra region, Magura Nappe, Western Outer Carpathians: an interference of West and East Carpathian fold trends (in Polish with English summary). Annales Soc. Geol. Polon., 55. 375-422.

AncZKiewicz, A. A., Środoń, J. \& ZAtTin, M. 2013. Thermal history of the Podhale Basin in the Internal Western Carpathians from the perspective of apatite fission trac analyses. Geologica Carpathica, 64, 141-151.

BALlA, Z. \& MÁRTON-SzAlAY, E. 1978. The palaeomagnetic sequence in the Börzsöny volcanic area 1 (in Hungarian). Magyar Geofizika, 19, 51-59.

Bazhenov, M., Began, A., Birkenmajer, K. \& Burtman, V.S., 1980. Paleomagnetic evidence of the tectonic origin of the curvature of the West Carpathian Arc. Bull. Ac. Pol. Sci. Ser. Sci. de Terr., 28, 281-290.

Besse, J., \& Courtillot, V., 1991. Revised and synthetic apparenat polar wander paths of the African, Eurasian, North American and Indian Plates, and true polar wander since 200 Ma. Journal of Geophysical Research, 96, B3, 4029-4050.

Besse, J., \& Courtillot, V., 2002. Apparent and true polar wander and geometry of the geomagnetic field over the last 200 Myr. Journal of Geophysical Research, 107 (B11), 6-1 - 6-31 EPM.

Besse, J., \& Courtillot, V., 2003. Correction to "Apparent and true polar wander and geometry of the geomagnetic field over the last 200 Myr". Journal of Geophysical Research, 108 (B10), 3-1 - 3-2 EPM.

BirkenMAJER, K. 1986. Stages of structural evolution of the Pieniny Klippen Belt, Carpathians. Studia Geologica Polonica, 80. 7-32.

Birkenmajer, K. \& NAIRN, A.E.M., 1968. Paleomagnetic studies of Polish rocks. III. Neogene igneous rocks of the Pieniny Mountains, Carpathians. Annales de la Société Geologique de Pologne, 38, 475-489.

BirkenMAJER, K. \& PÉCSKAY, Z. 2000. K-Ar dating of the Miocene andesite intrusions, Pieniny Mts, West Carpathians: a supplement. Studia Geologica Polonica, 117. 7-25.

BURTMAN, V.S. 1988. Kinematics of the Carpathian-Balkan region during Cretaceous and Cenozoic. Studia Geologica Polonica, 91, 39-60..

Channell, J.E.T., Kozur, H.W., Sievers, T., Mock, R., Aubrecht, R. \& Sykora, M. 2003. Carnian - Norian biomagnetostratigraphy at Silická Brezová (Slovakia): correlation to Rother Tethyan sections and to Newark Basin. Palaeogeography, Palaeoclimatology, Palaeoecology, 191, 65-109.

DanišIK, M., Kohut, M., Evans, N.J. \& MCDonald, B.J. 2012. Eo-Alpine metamorphism and the 'mid-Miocene thermal event' in the Western Carpathians (Slovakia): new evidence from multiple thermochronology. Geological Magazine, 149, 158-171.

Decker. K., Nescieruk, P., Reiter, F., Rubinkiewicz, J., RyŁKo, W. \& ToKARsKi A.K. 1997. Heteroaxial shortening, strike-slip faulting and displacement transfer in the Polish Carpathians. Przeglad Geologiczny, 45. 1070-1071. 
ENKIN, R.J. \& WATSON, G.S., 1996. Statistical analysis of paleomagnetic inclination data. Geophysical Journal International, 126, 495-504.

Fodor, L., Francu, J., KrejCI, O. \& StrÁnIK, Z. 1995. From transpression to transtension: Oligocene-Miocene structural evolution of the Vienna Basin and the Eastern AlpineWestern Carpathian junction. Tectonophysics, 242, 151-182.

FODOR, L. 2006. Tertiary tectonic evolution of the Pannonian_Carpathian-Eastern Alpine Domain: a personal view of from Pannonia in the light of the terminological question of tectonic units. Geolines, 20, 34-35.

Froitzheim N., Plašienka D. \& Schuster R. 2008. Alpine tectonics of the Alps and Western Carpathians. In: McCann, T. (ed) The Geology of Central Europe. Volume 2. Mesozoic and Cenozoic. Geological Society, London, 1141-1232.

Gągata, Ł., Vérges, J., Saura, E., Malata, T., Ringebach, J.-C., Werner, P. \& Krzywiec P. 2012. Architecture and orogenic evolution of the northeastern Outer Carpathians from cross-section balancing and forward modeling. Tectonophysics, 532, 223-241.

GALBRUN, B. 1985. Magnetostratigraphy of the Berriassian stratotype section (Berrias, France). Earth and Planetary Science Letters, 74, 130-136.

GrabowsKi, J. 1995. New paleomagnetic data from the Lower Sub-Tatric radiolarites, Upper Jurassic (Western Tatra Mts). Geological Quaterly, 39, 61-74.

GrabowsKi, J. 1997. Paleomagnetic results from the Cover (High Tatric) unit and Nummulitic Eocene in the Tatra Mts (Central West Carpathians, Poland) and their tectonic implications. Ann. Soc. Geol. Pol., 67, 13-23.

GRABOWSKI, J. 2000. Palaeo- and rock magnetism of Mesozoic carbonate rocks in the SubTatric series (Central West Carpathians) - palaeotectonic implications. Polish Geological Institute, Special Papers, 5, 1-88.

GRABOwsKI, J. 2005. New Berriasian palaeopole from the Central West Carpathians (Tatra Mountains, southern Poland): does it look Apulian? Geophysical Journal International 161, 65-80.

GrabowsKi, J. \& GAWĘDA, A. 1999.. Preliminary palaeomagnetic study of the High Tatra granites, Central West Carpathians, Poland. Geological Quarterly, 43, 263-276.

Grabowski, J., Krzemiński, L., Nescieruk, P., SzydŁo, A., Paszkowski, M., Pecskay, Z. \& WÓJTOWICZ, A., 2003. Geochronology of the teschenitic intrusions in the Outer Western Carpathians of Poland - constraints from ${ }^{40} \mathrm{~K} /{ }^{40}$ Ar ages and biostratigraphy. Geologica Carpathica, 54, 385-393.

GRABOWSKI, J. \& NEMČOK, M. 1999. Summary of paleomagnetic data from the Central West Carpathians of Poland and Slovakia: evidence for the Late Cretaceous - Early Tertiary transpression. Physics and Chemistry of the Earth, A 24, 681-685.

GRABOWSKI, J. \& PsZCZÓŁKOWSKI, A. 2006. Magneto- and biostratigraphy of the Tithonian Berriasian pelagic sediments in the Tatra Mountains (central Western Carpathians, Poland): sedimentary and rock magnetic changes at the Jurassic/Cretaceous boundary. Cretaceous Research, 27, 398-417.

GrabowsKi J., KRZEMiŃSKi, L., NescieruK, P. \& StARnAWSKA, E. 2006. Paleomagnetism of the teschenitic rocks (Lower Cretaceous) in the Outer Western Carpathians of Poland: constraints for the tectonic rotations in the Silesian unit. Geophysical Journal International, 166, 1077-1094. 
Grabowski, J., Krobicki, M., SobIEŃ, K. 2008. New palaeomagnetic results from the Polish part of the Pieniny Klippen Belt, Carpathians - evidence for the palaeogeographic position of the Czorsztyn Ridge in Mesozoic. Geological Quarterly, 52, 31-44.

Grabowski, J., Michalík J., Szaniawski, R. \& GroteK, I. 2009. Synthrusting remagnetization of the Krížna nappe: high resolution palaeo- and rock magnetic study in the Strážovce section, Strážovské vrchy Mts, Central West Carpathians (Slovakia). Acta Geologica Polonica, 59, 137-155.

Grabowski, J., Michalik, J., PszczóŁKowski, A. \& LintnerovÁ, O. 2010. Magneto- and isotope stratigraphy around the Jurassic/Cretaceous boundary in the Vysoka unit (Male Karpaty Mountains): correlations and tectonic implications. Geologica Carpathica, 61, 309-326.

Gradstein, F. M., OgG, J.G., Schmitz, M.D. \& OgG, G.M. (Eds.) 2012. The Geologic Time

Scale 2012. First ed. Elsevier BV.

HoušA, V., Krs, M., Krsova, M. \& Pruner P. 1996. Magnetostratigraphy of JurassicCretaceous limestones in the Western Carpathians. In: Morris, A., Tarling, D.H. (eds), 1996, Paleomagnetism and Tectonics of the Mediterranean region, Geological Society Special Publication, 105, 185-194.

JeleńskA, M., Túnyi, I. \& Aubrecht, R. 2011. Low latitude Oxfordian position of the Oravic crustal segment (Pieniny Klippen Belt, Western Carpathians): palaeogeographic implications. Palaeogeography, Palaeoclimatology, Palaeoecology, 302, 338-348.

KądZiałko-Hofmokl, M. \& KruCZYK, J. 1987. Paleomagnetism of middle-late Jurassic sediments from Poland and implications for the polarity of the geomagnetic field. Tectonophysics, 139, 53-66.

Karátson, D., Márton, E., Harangi, Sz., Józsa, S., Balogh, Kad., Pécskay, Z., Kovácsvölgyi, S., Szakmány, Gy. \& Dulai, A. 2000. Volcanic evolution and stratigraphy of the Miocene Börzsöny Mountains, Hungary: An integrated study. Geologica Carpathica, 51, 325-343.

Karátson, D., Oláh, I., Pécskay, Z., Márton, E., Harangi, Sz., Dulai, A. \& Zelenka, T. 2007. Miocene volcanism in the Visegrád Mountains (Hungary): an integrated approach to regional volcanic stratigraphy. Geologica Carpathica, 58, 541-563.

Korab, T., Krs, M., KrsovÁ, M. \& PAGÁČ, P. 1981. Paleomagnetic investigations of Albian (?)-Paleocene to Lower Oligocene sediments from the Dukla unit, East Slovakian Flysch, Czechoslovakia. Zapadne Karpaty, ser. Geologia, 7, 127-149.

KotÁseK, J. \& KRS, M. 1965. Palaeomagnetic study of tectonic rotation in the Carpathian Mountains of Czechoslovakia. Palaeogeography, Palaeoclimatology, Palaeoecology, 1, 39-49.

KRS, M., MuŠKA, P. \& PAGAČ, P., 1982. Review of paleomagnetic investigations in the West Carpathians of Czechoslovakia. Geologicke prace, Spravy, Geological Institute of Dionyz Stur, Bratislava, 78, 39-58.

Krs, M., Krsová, M., ChvojKa, R. \& Potfaj, M. 1991. Paleomagnetic investigations of the flysch belt in the Orava region, Magura unit, Czechoslovak Western Carpathians. Geologicke prace, Dionýz Stúr Geological Institute, Bratislava, 92, 135-151. 
Krs, M., ChVojKa, R. \& Potfaj M. 1993. Paleomagnetic investigations in the Biele Karpaty Mts unit, flysch belt of the Western Carpathians. Geologica Carpathica, 45, 35-43.

Krs, M., Krsova, M. \& Pruner, P., 1996. Paleomagnetism and paleogeography of the Western Carpathians from the Permian to the Neogene. In: Morris, A., Tarling, D.H. (eds), 1996, Paleomagnetism and Tectonics of the Mediterranean region, Geological Society Special Publication, 105, 175-184.

KRS, M. \& ŠMID, B., 1979. Palaeomagnetism of Cretaceous rocks of the teschenite association, Outer West Carpathians, Czechoslovakia. Sb. Geol. Ved. Uzita Geof., 16, $7-22$.

Kruczyk, J., Kądzialko-Hofmokl, M., Lefeld, J., Pagač, P. \& Túnyi, I. 1992. Paleomagnetism of Jurassic sediments as evidence for oroclinal bending of the Inner West Carpathians. Tectonophysics, 206, 315-324.

Kruczyk, J., Kądzialko-Hofmokl, M., Túnyi, I., Pagač, P., \& Mello, J., 1998 Paleomagnetic study of Triassic sediments from the Silica nappe in the Slovak Karst, a new approach. Geologica Carpathica, 49, 33-43.

KSIĄŻKIEWICZ, M. 1960. Pre-orogenic sedimentation in the Carpathian geosyncline. Geologische Rundschau, 50, 8-31.

KsiAŻKIEWICZ, M. 1977. Tectonics of the Carpathians. In: Pozaryski, W. (ed) Geology of Poland. v. IV, Tectonics. Wydawnictwa Geologiczne, Warsaw, 476-604.

Lewandowski, M., Krobicki, M., Matyja, B. A. \& Wierzbowski, A. 2005. Palaeogeographic evolution of the Pieniny Klippen Basin using stratigraphic and palaeomagnetic data from the Veliky Kamenets section (Carpathians, Ukraine). Palaeogeography, Palaeoclimatology, Palaeoecology, 216, 53-72.

LeXa, J., BezÁK, V., ElečKo, M., Mello, J., PolÁk, M., Potfaj, M. \& VozÁr, J. (Eds.) 2000. Geological map of Western Carpathians and adjacent areas 1: 500,000. Ministry of Environment of Slovak Republic, Geological Survey of Slovak Republic.

LuCiŃSKA-ANCZKIEwiCZ, A., Villa, I.M., ANCZKIEwICZ,R. \& ŚLĄCZKA, A. 2002. ${ }^{40} \mathrm{Ar} /{ }^{39} \mathrm{Ar}$ Dating of Alkaline Lamprpphyres from the Polish Western Carpathians. Geologica Carpathica, 53, 45-52.

MCCABE, C. \& Elmore, R. D. 1989. The occurrence and origin of late Paleozoic remagnetization in the sedimentary rocks of North America. Rev. Geophys., 27, 471494.

MÁrton, E. \& MÁrTOn, P. 1996. Large scale rotations in North Hungary during the Neogene as indicated by palaeomagnetic data. In: Morris, A. \& Tarling, D.H. (eds) Palaeomagnetism and Tectonics of the Mediterranean Region. Geological Society, London, Special Publication, 105, 153-173.

MÁrton, E., MÁrton, P. \& Less, Gy. 1988. Paleomagnetic evidence of tectonic rotations in the Southern margin of the Inner West Carpathians. Physics of the Earth and Planetary Interiors, 52, 256-266.

MÁrton, E., PAGÁČ, P. \& TÚNYI, I. 1992. Paleomagnetic investigations on late CretaceousCenozoic sediments from the NW part of the Pannonian Basin. Geologica Carpathica, 43, 363-368. 
MÁRTON, E., VASS, D. \& TúNYI, I. 1996. Rotation of the South Slovak Paleogene and Lower Miocene rocks indicated by paleomagnetic data. Geologica Carpathica, 47, 31-41.

MÁrton, E. \& PÉCSKAY, Z. 1998. Correlation and dating of the Miocene ignimbritic volcanics in the Bükk foreland, Hungary: complex evaluation of paleomagnetic and $\mathrm{K} / \mathrm{Ar}$ isotope data. Acta Geologica Hungarica, 41, 467-476.

MÁrton, E., MASTELlA, L. \& TOKARSKi A.K. 1999. Large counterclockwise rotation of the Inner West Carpathian Paleogene Flysch - evidence from paleomagnetic investigation of the Podhale Flysch (Poland). Physics and Chemistry of the Earth, 24, 645-649.

MÁRTON, E., VASS, D. \& TúNYI, I. 2000. Counterclockwise rotations of the Neogene rocks in the East Slovak Basin. Geologica Carpathica, 51, 159-168.

MÁrton, E., ToKARski, A. K. \& HALÁsz, D. 2004. Late Miocene counterclockwise rotation of the Pieniny andesites at the contact of the Inner and Outer West Carpathians. Geologica Carpathica, 55, 411-419.

Márton, E., VAss, D., Túnyi, I., Márton, P. \& Zelenka, T. 2007a. Paleomagnetic age assignment of the ignimbites from the famous fossil footprints site, Ipolytarnóc (close to the Hungarian-Slovakian boundary). Geologica Carpathica, 58, 531-540.

Márton, E., Zelenka, T. \& Márton, P. 2007b. Paleomagnetic correlation of Miocene pyroclastics of the Bükk Mts. and their forelands. Central European Geology, 50, 4757. doi: 10.1556/CeuGeol.50.2007.1.4.

Márton, E., Tischler, M., Csontos, L., Fügenschuh, B. \& Schmid, S. M. 2007c. The contact zone between ALCAPA and Tisza-Dacia megatectonic units of Northern Romania in the light of new paleomagnetic data. Eclogae geologicae Helvetiae, 100, $109-124$.

MÁrton, E., Rauch-WŁodarska, M., KrejČI, O., ToKArski, A.K. \& BubiK, M. 2009a. An integrated palaeomagnetic and AMS study of the Tertiary flysh from the Outer Western Carpathians. Geophysical Journal International, 177, 925-940, doi: 10.1111/j.1365-246X.2009.04104x.

Márton, E., Jeleńska, M., Tokarski, A.K., Soták, J., Kováč, M. \& SpišiaK, J. 2009b. Current-independent paleomagnetic declinations in flysch basins: a case study from the Inner Carpathians. Geodinamica Acta, 22, 73-82. doi: 10.3166/ga.22.73-82.

MÁrton, E., Zampieri, D., Grandesso P., Ćosović, V., Moro, A. 2010. New Cretaceous paleomagnetic results from the foreland of the Southern Alps and the refined apparent polar wander path for stable Adria. Tectonophysics, 480, 57-72.

Márton, E., Tokarski, A.K., Krejči, O., Rauch, M., Olszewska, B., Petrová P.T. \& WóJCIK, A. 2011. 'Non-European' palaeomagnetic directions from the Carpathian Foredeep at the southern margin of the European plate. Terra Nova, 23, 134-144, doi: 10.1111/j.1365-3121.2011.00993.x.

Márton, E., Grabowski, J., Plašienka, D., Túnyi, I., Krobicki, M., HaAs, J. \& Pethe, M. 2013. New paleomagnetic results from the Upper Cretaceous red marls of the Pieniny Klippen Belt, Western Carpathians: evidence for general CCW rotation and implications for the origin of the structural arc formation. Tectonophysics, 592, 1-13.

MÁRTON, P., RozložNiK, L., SASVARI, T., 1991. Implications of paleomagnetic study of the Silica nappe, Slovakia. Geophysical Journal International, 107, 67-75. 
MAStella, L. \& KonON, A. 2002. Jointing in the Silesian Nappe (Outer Carpathians, Poland) - Paleostress reconstruction. Geologica Carpathica, 53. 315-325.

MAURITSCH, H.J. \& MÁRTON, E., 1995 - Escape models of the Alpine-Carpathian-Pannonian region in the light of paleomagnetic observations. Terra Nova, 7, 44-50.

Muttoni, G., Erba, E., Kent, D.V. \& Bachtadse, V. 2005. Mesozoic Alpine facies deposition as a result of past latitudinal plate motion. Nature, 434, 59-63.

Muttoni, G., Dallanave, E. \& Channell, J.E.T. 2013. The drift history of Adria and Africa from $280 \mathrm{Ma}$ to Present, Jurassic true polar wander and zonal climate control on Tethyan sedimentary facies. Palaeogeography, Palaeoclimatology, Palaeoecology, 386, 415-435.

NeMČOK, M. \& NEMČOK, J., 1994. Late Cretaceous deformations of the Pieniny Klippen Belt, Western Carpathians. Tectonophysics, 239, 81-109.

NemČoK, M., PosPisil, L., LeXA, J. \& Donelick, R. A. 1998, Tertiary subduction and slab break-off model of the Carpathian-Pannonian region. Tectonophysics, 295, 307-340.

NemČoK M., NemčoK J., Wojtaszek M., Ludhova L., Klecker R.A., Sercombe W.J., COWARD M.P. \& KEITH J.F. JR. 2000. Results of 2D balancing along $20^{\circ}$ and $21^{\circ} 30^{\prime}$ langitude and pseudo-3D in the Smilno tectonic window: Implications for shortening mechanisms of the West Carpathian accretionary wedge. Geologica Carpathica, 51, 281-300.

NemČoK, M., Krzywiec, P., Wojtaszek, M., LudhovÁ, L., Klecker, R.A., Secombe, W.J. \& COWARD, M.P. 2006: Tertiary development of the Polish and eastern Slovak parts of the Carpathian accretionary wedge: insights from balanced cross-sections. Geologica Carpathica, 57, 355-370.

Opdyke, N.D. \& Channell, J. E. T. 1996. Magnetic stratigraphy. Academic Press, San Diego, 346 pp.

ORLICKÝ, O. 1996. Paleomagnetism of Neovolcanics of the East-Slovak lowlands and Zemplínske Vrchy Mts.: A study of the tectonics applying the paleomagnetic data (Western Carpathians). Geologica Carpathica, 47, 13-20.

OsczypKo, N. \& OszczypKo-Cloves, M. 2006. Evolution of the Magura Basin (in Polish, English abstract). In: Oszczypko, N., Uchman, A. \& Malata, E. (eds) Palaeotectonic evolution of the Outer Carpathians and Pieniny Klippen Belt basins. Institute of Geological Sciences, Jagiellonian University, Cracow, 133-164.

OsZCZYPKO, N. \& SlACZKA, A. 1985. An attempt at palinspastic reconstruction of Neogene basin in the Carpathian foredeep. Annales Societatis Geologorum Poloniae, 55, 55-75.

Oszczypko, N., Krzywiec, P., Popadyuk, I. \& Peryt T. 2005. Carpathian Foredeep Basin (Poland and Ukraine): Its sedimentary, structural and geodynamic evolution. In: Golonka, J. \& Picha, J. (eds) The Carpathians and their foreland. Geology and hydrocarbon resources. AAPG Memoir, 84, 293-350.

Picha, F., Stranik, Z. \& KREJČI, O. 2005. Geology and hydrocarbon resources of the Outer Western Carpathians and their foreland, Czech Republic. In: Golonka, J. \& Picha, F. 
(eds) The The Carpathians and their foreland: Geology and hydrocarbon resources. AAPG Memoir, 84, 49-175

Piotrowski, J., 1978. Mesostructural analysis of the main tectonic units of the Tatra Mountains along the Koœcieliska Valley, (in Polish, English summary). Studia Geologica Polonica, 55, 3-90.

PlaŠIENKA, D. 1995. Passive and active margin history of the northern Tatricum (Western Carpathians, Slovakia). Geologische Rundschau, 84, 748-760.

PlaŠIENKA, D. 2012a. Early stages of structural evolution of the Carpathian Klippen Belt (Slovakian Pieniny sector). Mineralia Slovaca, 44, 1-16.

PlAŠIENKA, D. 2012b. Jurassic syn-rift and Cretaceous syn-orogenic, coarse grained deposits related to opening and closure of the Vahic (South Penninic) Ocean in the Western Carpathians - an overview. Geological Quarterly, 56, 601-628.

PlašienKa, D., Grecula, P., Putiš, M., KovÁČ, M. \& Hovorka, D., 1997._Evolution and structure of the Western Carpathians: an overview. In: Grecula, P., Hovorka, P. \& Putiš, M. (eds) Geological evolution of the Western Carpathians. Mineralia Slovaca Monograph, Bratislava, 1-24.

PókA, T., Zelenka, T., Seghedi, I., PÉCSKAy, Z. \& MÁRton, E. 2004. Miocene volcanism of the Cserhát Mts. (N. Hungary): Integrated volcano-tectonic, geochronologic and pertochemical study. Acta Geologica Hungarica, 47, 221-246.

ProkeŠOVA, R., PlašIENKA, D. \& Milovsky, R. 2012. Structural pattern and emplacement mechanism of the Križna cover nappe (Central Western Carpathians). Geologica Carpathica, 63, 13-32.

Pruner, P., Venhodová, D. \& SlepičKovÁ, J. 1998. Palaeomagnetic and palaeotectonic studies of selected areas of Tatricum, Manin and Križna units. In: Rakus, M. (ed) Geodynamic development of the Western Carpathians. Geological Survey of Slovak Republic, Bratislava, 281-290.

Pueyo, E.L., Mauritsch, H.J., Gawlick, H-J., Scholger, R. \& Frisch, W. 2007. New evidence for block and thrust sheet rotations in the central northern Calcareous Alps deduced from two pevasive remagnetization events. Tectonics, 26, TC5011, doi: 10.1029/2006TC001965.

Ratschbacher, L., Frisch, W., Linzer, H.G., Sperner, B., Meschede, M., Decker, K., NemČOK, M., NemČOK, J. \& GRYGar, R. 1993. The Pieniny Klippen Belt in the Western Carpathians of northeastern Slovakia: structural evidence for transpression. Tectonophysics, 226, 471-483.

RöGL, F. 1996. Stratigraphic correlation of the Paratethys Oligocene and Miocene. Mitt. Ges. Geol. Bergbaustud. Österr., 41, 65-73.

SPERNER, B., RATSCHBACHER, L. \& NEMČOK, M. 2002. Interplay between subduction retreat and lateral extrusion: tectonics of the Western Carpathians. Tectonics, 21, 1051-1075.

ŚlączKa A., KrugŁow S., Golonka J., OszczypKo N. \& Popadyuk I. 2005. Geology and hyrocarbon resources of the Outer Carpathians, Poland, Slovakia and Ukraine. In: Golonka, J. \& Picha, J. (eds) The Carpathians and their foreland, Geology and hydrocarbon resources. AAPG Memoir, 84, 221-258.

Środoń, J., Kotarba, M., Biron, A., Such, P., Clauer N. \& WóJtowicz, A. 2006. Diagenetic history of the Podhale-Orava basin and the underlying Tatra Sedimentary 
units (Western Carpathians): evidence from XRD and K-Ar of illite-smectite. Clay Minerals, 41, 751-774.

SZANIAWSKI, R., LUDWINIAK, M. \& RUBINKIEWICZ, J. 2012. Minor counter-clockwise rotation of the Tatra Mountains (Central West Carpathians) as derived from paleomagnetic results achieved in hematite bearing Lower Triassic sandstones. Tectonophysics, $\mathbf{5 6 0}$ 561, 51-61.

Szaniawski, R., Mazzoli, S., Jankowski, L. \& Zattin, M. 2013. No large-magnitude rotations of the Subsilesian Unit of the Outer Western Carpathians: evidence from primary magnetization recorded In hematite-bearing Węglówka Marls (Senonian to Eocene). Journal of Geodynamics, 71, 14-24.

ŚwIERCZEWSKA A. \& ToKARSKI A.K. 1998. Deformation bands and the history of folding in the Magura Nappe, Western Outer Carpathians (Poland). Tectonophysics, 297, 73-90.

Tokarski, A. K., Swierczewska, A. \& Zuchiewicz, W. 2007. Fractured clasts in neotectonic reconstructions: An example from the Nowy Sacz Basin, Western Outer Carpathians, Poland. Studia Quaternaria, 24, 47-52.

TOMEK, Č. \& Hall, J. 1993. Subducted continental margin imaged in the Carpathians of Czechoslovakia. Geology, 21, 535-538.

Tominaga, M., Sager, W.W., Tivey, M.A. \& Lee, S-M. 2008. Deep tow magnetic anomaly study of the Pacific Jurassic Quiet Zone and implications for the geomagnetic polarity reversal timescale and geomagnetic field behaviour. Journal of Geophysical Research, 113, B07110, doi: 10.1029/2007JB005527.

Torsvik T.H., Van der Voo, R., Preeden, U., MacNiocaill, C., Steinberger, B., Dobrouvine, P.V., van Hinsbergen, D.J.J., Domeier, M., Gaina, C., Tohver, E., MeERT, J.G., McCAusland, P.J.A., \& CoCKS, L.R.M. 2012. Phanerozoic polar wander, palaeogeography and dynamics. Earth Science Reviews, 114, 325-368.

TÚNYI, I. \& MÁRTON, E. 1996. Indications for large Tertiary rotation in the CarpathianNorthern Pannonian region outside the North Hungarian Paleogene Basin. Geologica Carpathica, 47, 43-49.

TúnYi, I., MÁRton, E., VAss, D. \& ŽEC, B. 2004. Results of paleomagnetic study in the Vihorlatské vrchy Mts. (East Slovakia). Scripta Facultatis Scientiarium Naturalium Universitatis Masarykiance Brunensis, 31-32, 129-132.

VAn Der VoO, R., 1993. Paleomagnetism of the Atlantic, Tethys and Iapetus Oceans. Cambridge University Press.

WóJcik, A. \& Jugowiec, M. 1998. The youngest members of the folded Miocene in the Andrychów region (Southern Poland). Przeglad Geologiczny, 46, 763-770.

Zattin, M., Andreucci, B., Jankowski, L., Mazzoli, S. \& Szaniawski, R. 2011. Neogene exhumation in the Outer Western Carpathians. Terra Nova, 23, 283-291.

ZelenkA, T., PÓKA, T., MÁrton, E. \& PÉCSKAy, Z. 2005. New data on stratigraphic position of the Tar Dacite Tuff Formation (in Hungarian). Magyar Állami Földtani Intézet Évi Jelentése 2004, 73-84.

Zuchiewicz, W., TokArski, A.K., JARosiński, M., MÁrton E. 2002. Late Miocene to present day structural development of the Polish segment of the Outer Carpathians. Stephan Mueller Special Publication Series, 3, 185-202. 


\section{Figure captions}

Fig. 1. The geological build-up of the Western Carpathians. Simplified geological map of the area (modified after Lexa et al. 2000) and the location of the cross section ABC. The inset shows the location of the Western Carpathians in the East Alpine-CarpathianPannonian system (a). The NNW-SSE oriented cross section shows the positions of most of the tectonostratigraphic units of the Westrn Carpathians (b).

Note that the sediments of the Central Carpathian Palogene basin were preserved in one larger (surrounding the High Tatra Mts.) and in several smaller outcroping areas, and the Palaeogene rocks of the Internal Carpathian Palogene basin are accessible in outcrops also in the areas covered by Neogene sediments and volcanics.

Fig. 2. Basement map of the Inner Western Carpathians (simplified after Plašienka et al. 1997). The map shows the locations of the most important 'core mountains' which are the High Tatra (Tatry), the Low Tatra (N. Tatry), the Little Fatra (M. Fatra), the Innovec and the Little Carpathians (M. Karpaty).

Fig. 3. Structural scheme of the Western Carpathians and adjacent areas (after Lexa et al. 2000, slightly modified) with distribution of palaeomagnetic results (palaeodeclinations) obtained from the Palaeozoic and Mesozoic rocks, with age of magnetization indicated. Arrow (palaeodeclination) number corresponds to the entries in the Table 1. Rectangle indicates area presented in the Fig. 4. Some Palaeozoic declinations show two alternative interpretations of vertical axes rotations (clockwise and counter-clockwise).

Fig. 4. Geological sketch of the middle part of the Inner Carpathians (after Lexa et al. 2000, slightly modified) with all available palaeomagnetic data indicated.

Arrow (palaeodeclination) number corresponds to the entries in Tables 1 (black numbers) and 2 (grey numbers). Big arrow indicates result based on several sites or detailed magnetostratigraphic study in a single section; small arrow indicate result based on single locality. For lithological key (except items 15a-c) and other explanations, see Fig. 3. 15a - Fatric unit, sediments; 15b - Tatricum, sedimentary cover, $15 \mathrm{c}-$ Hronic unit, sediments. 
Fig. 5. Palaeomagnetic declinations obtained from Cenozoic rocks and two localities of the Upper Cretacous red marls from the Pieniny Klippen belt with post-folding remanence. Numbers up to 33 refer to Table 2, 46a and 46b to Table 1.

Fig. 6. Palaeomagnetic locality mean directions (providing the entry data for calculating overall-mean paleomagnetic directions tabulated in Table 2) from the dominantly Paleogene sediments (squares) from the Silesian (Table 2, rows 1a-d) and Magura nappes (Table 2, row 4) of the Outer Western Carpathians, from the Central (Table 2, row 7) and Inner Carpathian (Table 2, rows 13-15, 17 and 18) Paleogene basins, from the latest Cretaceous red marls (Table 1, rows 45 and 46) of the Pieniny Klippen belt (dots and circles) and from the igneous rocks of the Pieniny Klippen Belt (Table 2, row 6) and of the Inner Carpathian Paleogene basin (Table 2, rows 16, 19 and 20). Stereographic projections, full/empty symbols are vectors pointing downwards/upwards, representing vectors with positive and negative inclinations, respectively.

Figs 6a (before tilt corrections) and 6b (after tilt corrections) show the paleomagnetic directions interpreted as of pre-folding/tilting age. Note that in the Pieniny Klippen belt overturned strata also occur and these have negative inclinations before and positive after tectonic corrections.

Figs $6 \mathrm{c}$ (after tilt corrections) and 6d (before tilt corrections) show the paleomagnetic directions interpreted as of post-folding/tilting age from the PKB (Table 1, rows 46a and 46b), from the Magura nappe (Table 2, row 4) and from the Silesian nappe (Table 2 , row 1d).

Fig. 7. Palaeomagnetic directions with confidence circles for the Palaeogene rocks of the Outer Carpathian nappes, the Upper Cretaceous red marls and the Miocene andesites of the Pieniny Klippen belt and the overstep sequences of the Internal Carpahians. Stereographic projections, all directions are plotted as of normal polarity. It is documented that the Miocene overall rotations of the Outer Carpahian nappes (Silesian, Dukla and Magura Table 2, items 1 - prefolding, 1d - postfolding, 2 synfolding, 4 - postfolding respectively), the Pieniny Klippen belt (Upper Cretaceous red marls, Table 1, item 45 - prefolding, Pieniny andesites, Table 2, item 6) and the Podhale-Levoča basin (Table 2, item 7) are the same (a), that the Palaeogene sediments (single localities) outside of the Podhale-Levoca basin (Table 2, items 8-12) 
also exhibit large CCW rotations (b) that the Podhale-Levoča basin rotated in coordination with the Internal Carpathian Palogene basin (Table 2, items 16, 18-20) during the Miocene (c). The net Miocene rotation is the results of two rotational phases, since younger that 17.7 Ma rocks from the Internal Carpathian Palogene basin (Table 2, items 21-23, 25, 27 and 28) exhibit only moderate CCW rotation (d) and by the time the rotations are over there (Table 2, items 24, 28-30), they are still going on (Table 2, items 31 and 32) in the East Slovak basin (e).

Fig. 8. Correlation between local tectonic strikes and AMS lineations in the Silesian and Dukla Nappes, due to compressional tectonics.

Fig. 9. Palaeolatitudinal drift of the Inner Carpathians and Pieniny Klippen Belt in the Mesozoic. Numbers corresponds to entries in Table 2. Asterisk (*) denote data from Jeleńska et al. (2011) not enclosed into the Table 1. 
Fig. 1.

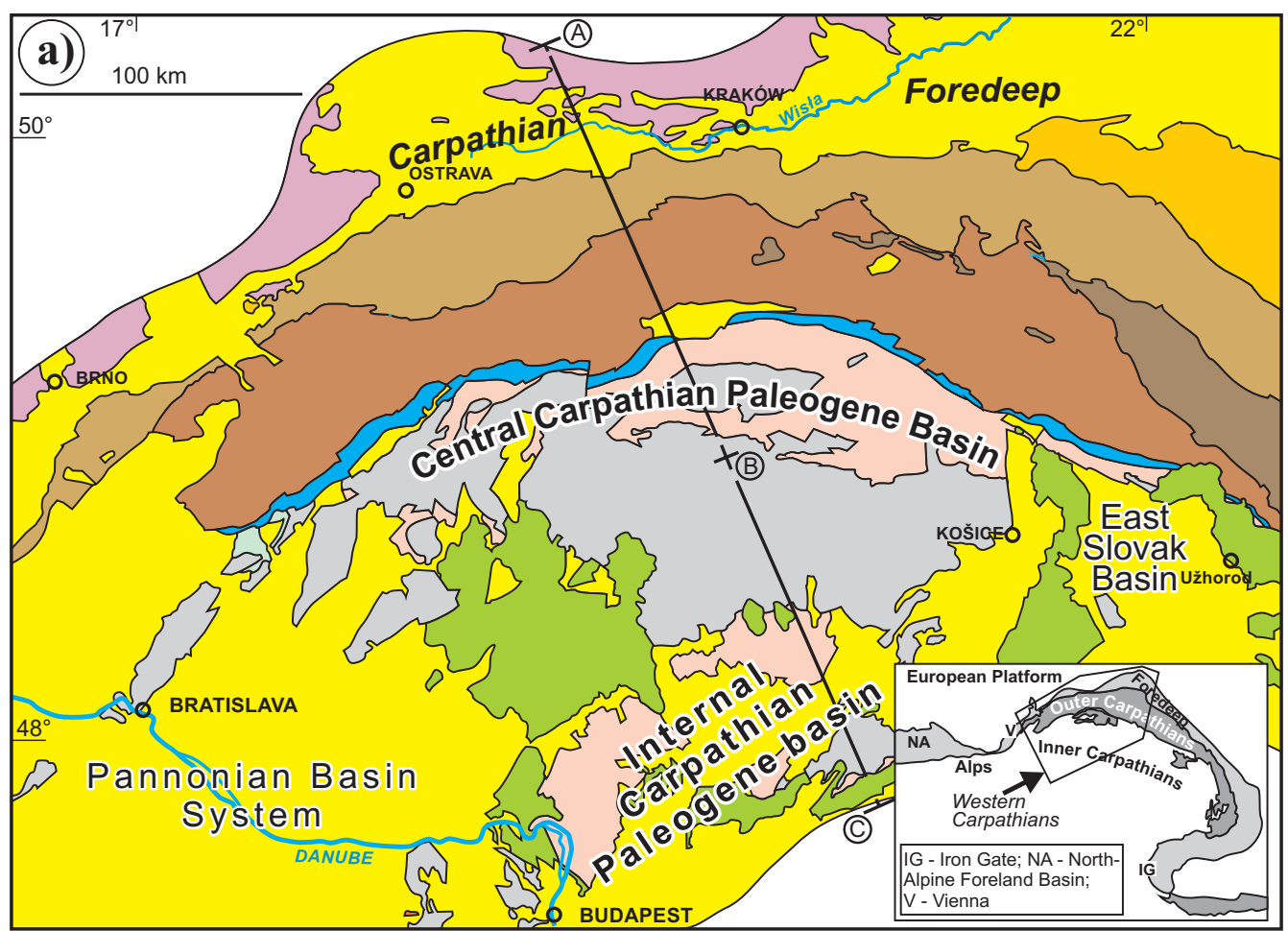

(b)
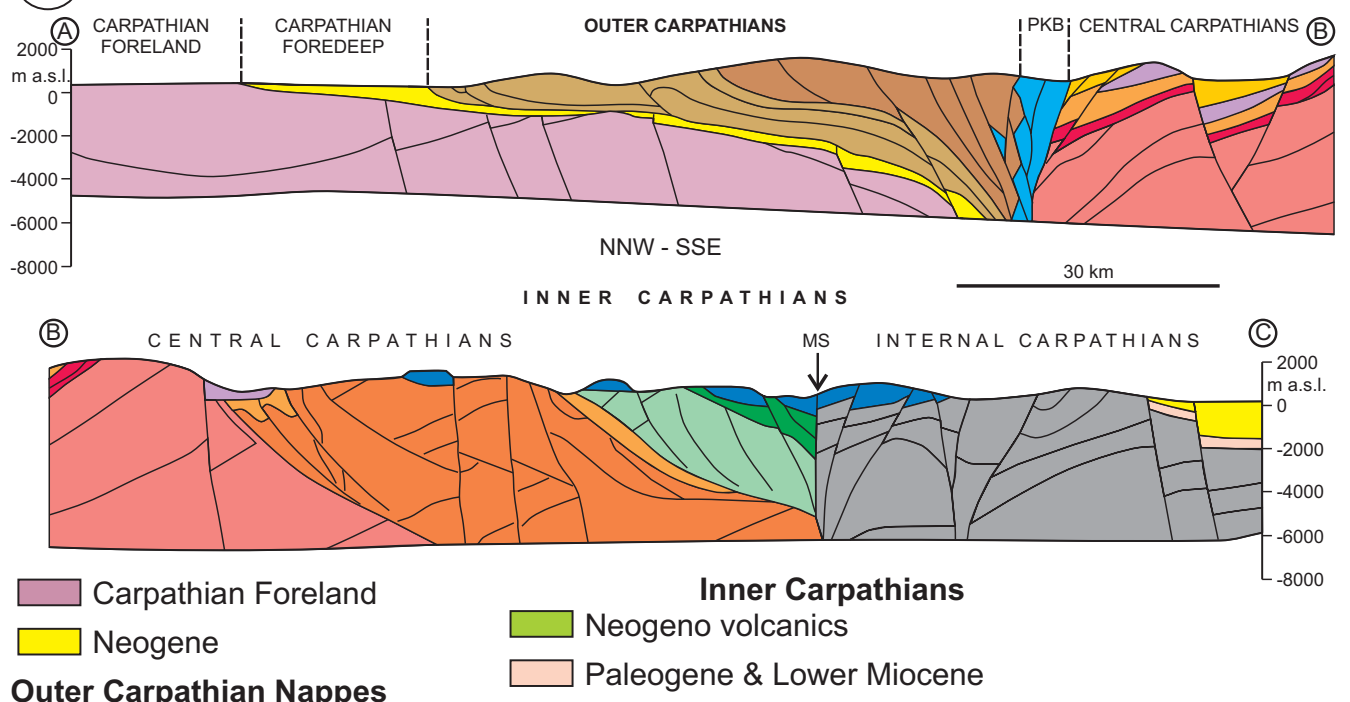

Outer Carpathian Nappes

$\square$ Skole $\quad \square$ Dukla
$\square$ Silesian $\square$ Magura
+Subsilesian

\section{Sutures}

$\square$ Pieniny Klippen Belt (PKB)

$\square$ Meliata (MS)

\section{Nappe stacks}

$\square$ Paleozoic \& Mesozoic (undivided on the mapp)

$\square$ Tatric cover $\square$ Tatric basement

$\square$ Veporic cover $\square$ Veporic basement

$\checkmark$ Hronic $\square$ Gemeric $\square$ Silicik

Transdanubian \& Bükk belts 
Fig. 2.

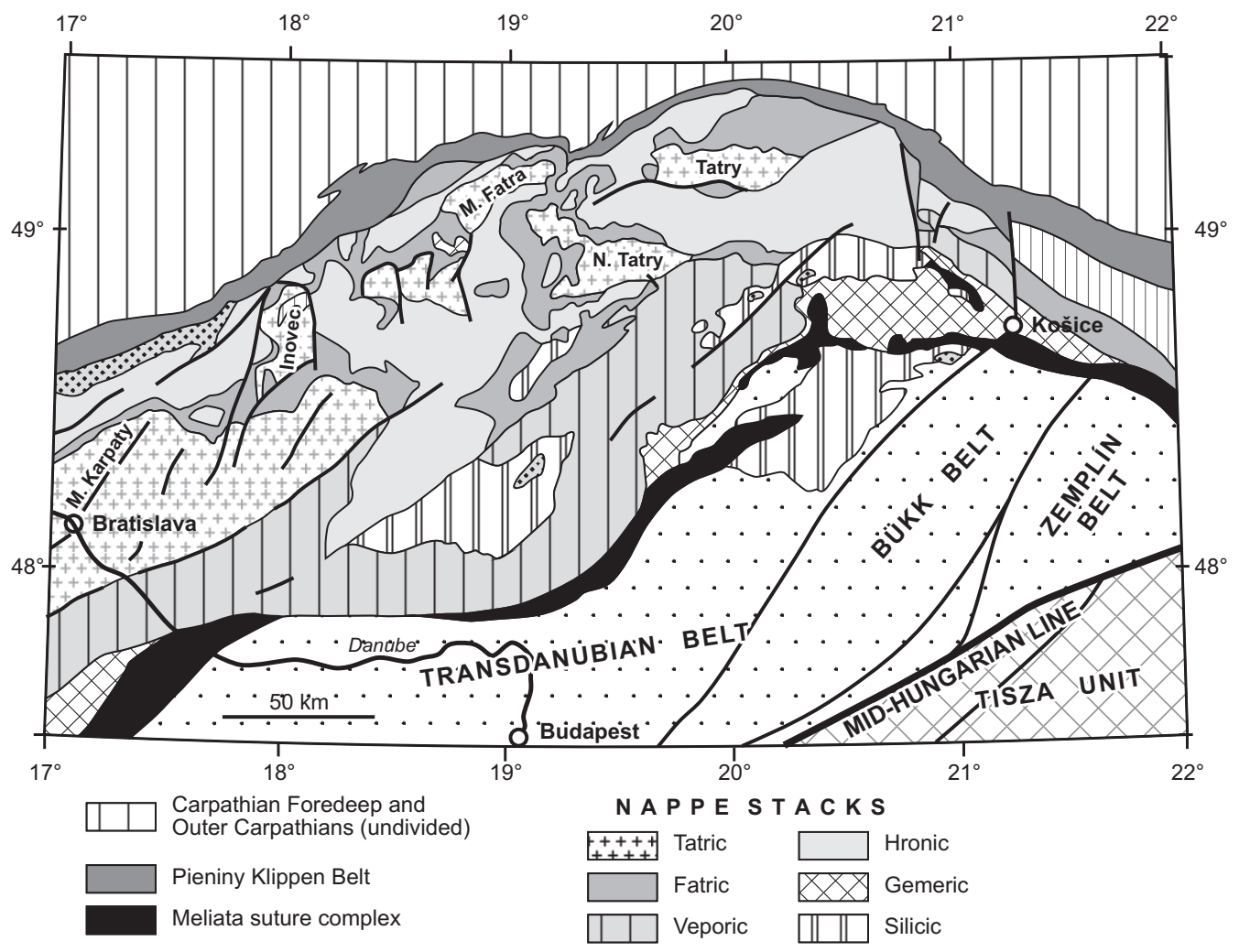

$\therefore \quad$ Upper Cretaceous sediments (Gosau)

$\therefore$ filling intramontane basins

|[I] Vahic oceanic elements 
Fig. 3.

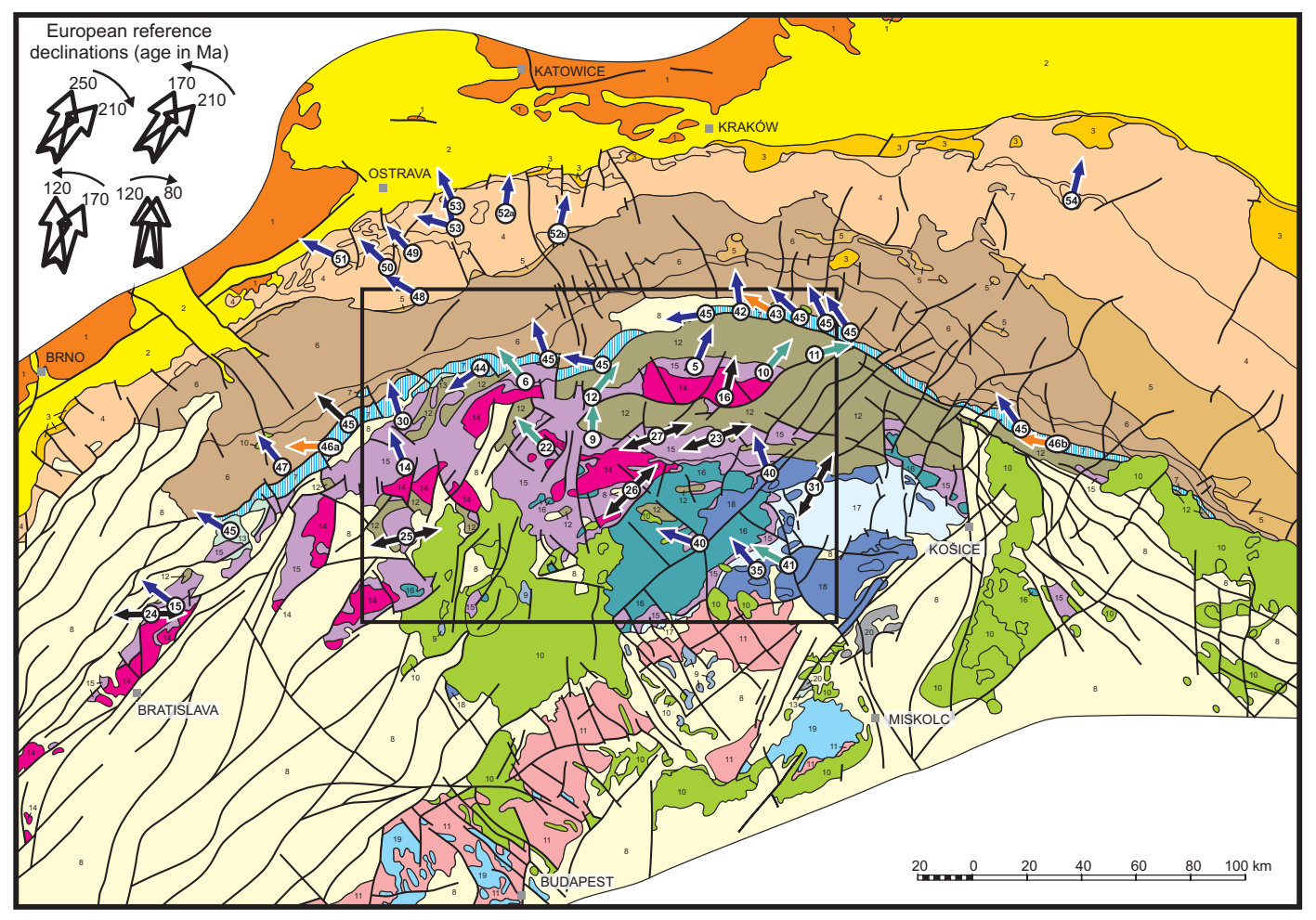

Carpathian Foreland

Foredeep: Neogene sedimentary
rocks of unfolded molasse

of the flysch belt

Krosno group of the flysch belt
(Skole, Sub-Silesian, Silesian nappes),

Fore-Magura and Dukla nappes

Magura nappe

Pieniny Klippen Belt

Neogene basins of the Inner Carpathians

Alkali basalts (Pannonian - Quaternary)

Andesitic volcanic rocks (Neogene)

Buda Basin (Eocene - Early Miocene)

Central Carpathian Paleogene

Gosau and Myjava Basins
(Late Cretaceous to Eocene)

Tatric crystalline basement

Tatric sedimentary cover,
Fatric and Hronic units

Veporic crystalline basement

7 Gemeric crystalline basement

8 Silicic unit

Dinaricum (Bukk Mts

20 Uppony Szendro Paleozoic

Age of magnetization:

$\uparrow \begin{aligned} & \text { Mesozoic } \\ & \text { primary }\end{aligned} \mid \begin{aligned} & \text { Mesozoic } \\ & \text { secondary }\end{aligned}$ Palaeozoic 
Fig. 4 .

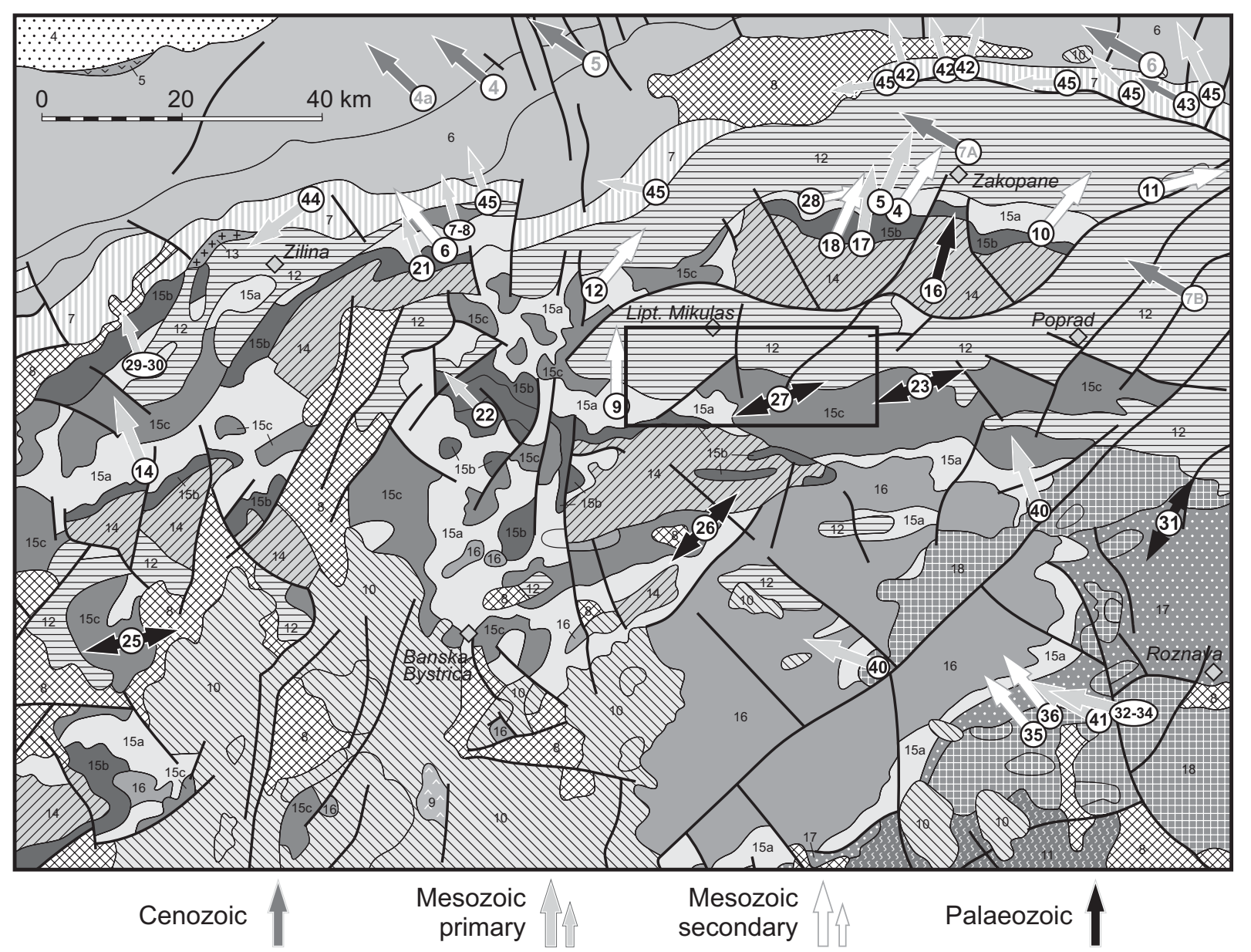

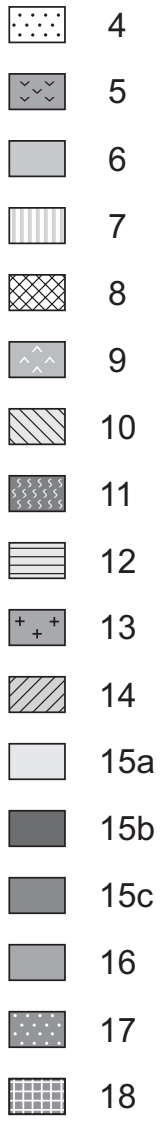


Fig. 5.

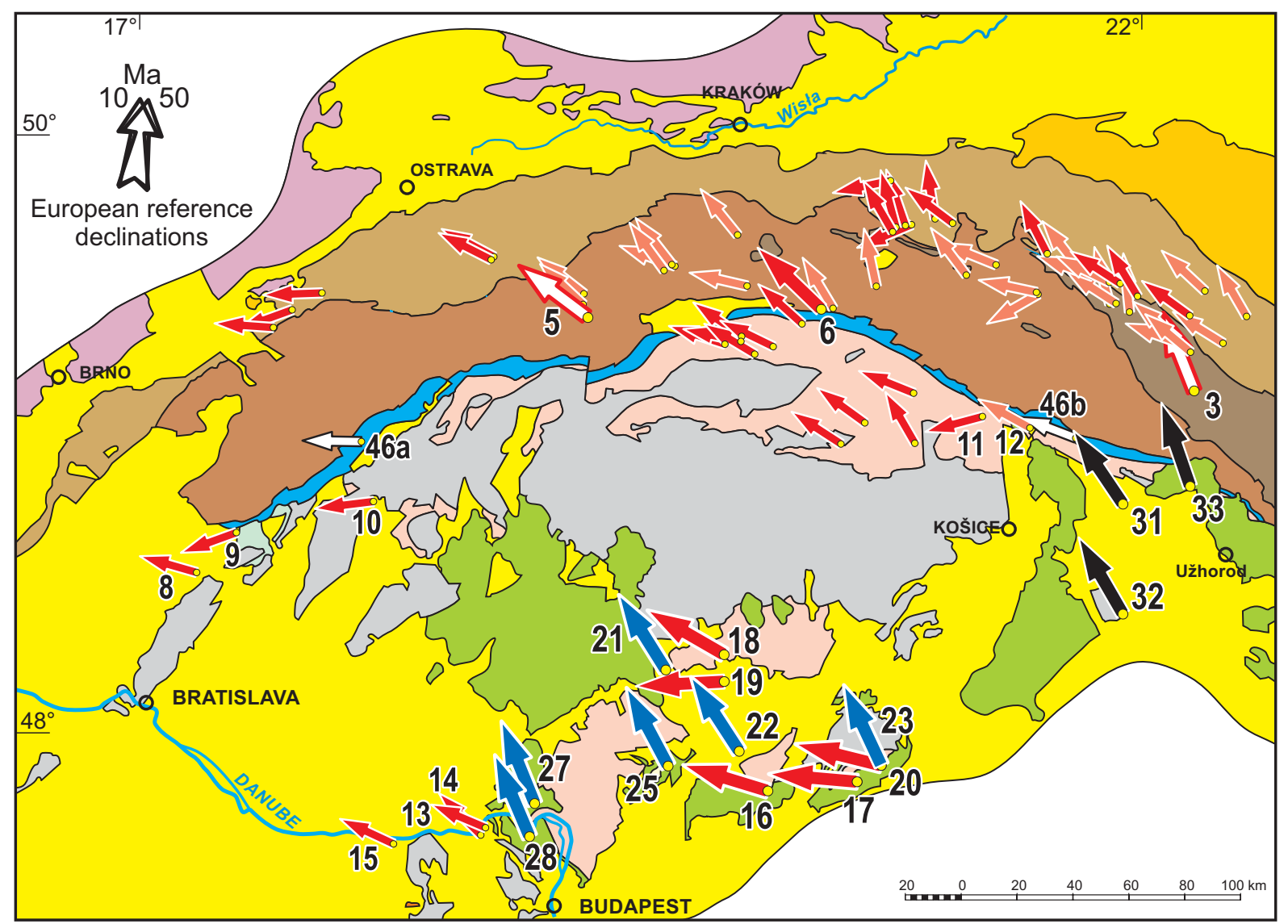

palaeomagnetic declinations obtained from

Paleogene - Early Miocene rocks

single localities

$\checkmark$ primary

$\rightarrow$ secondary overall mean declination

$\rightarrow$ primary

2 without full post Early Miocene rocks overall mean declination primary (17.5-16 Ma)

rotations ended later (only around 11.5 Ma)
Cretaceous sediments of the PKB, negative within locality fold test 
Fig. 6.

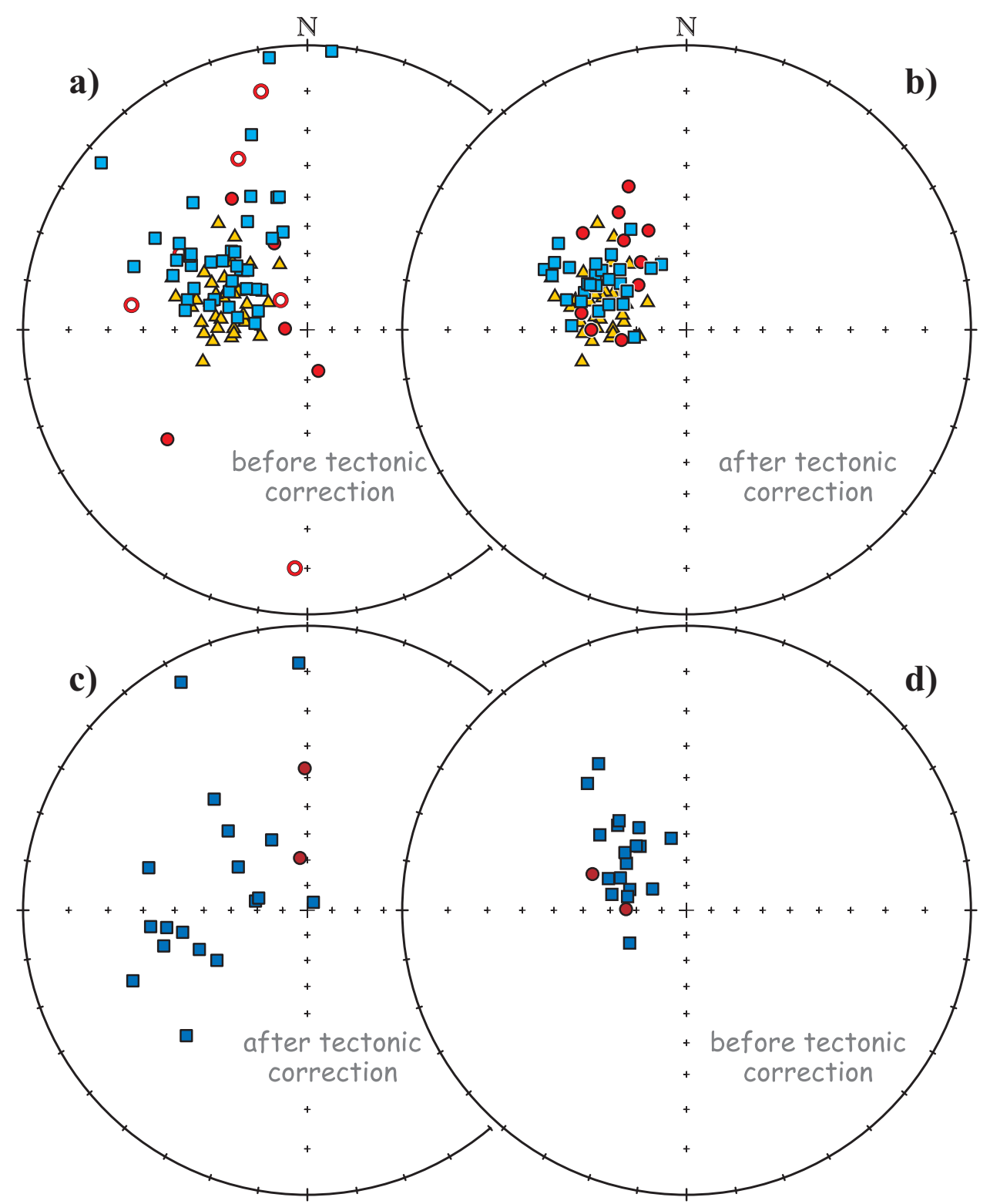


Fig. 7.

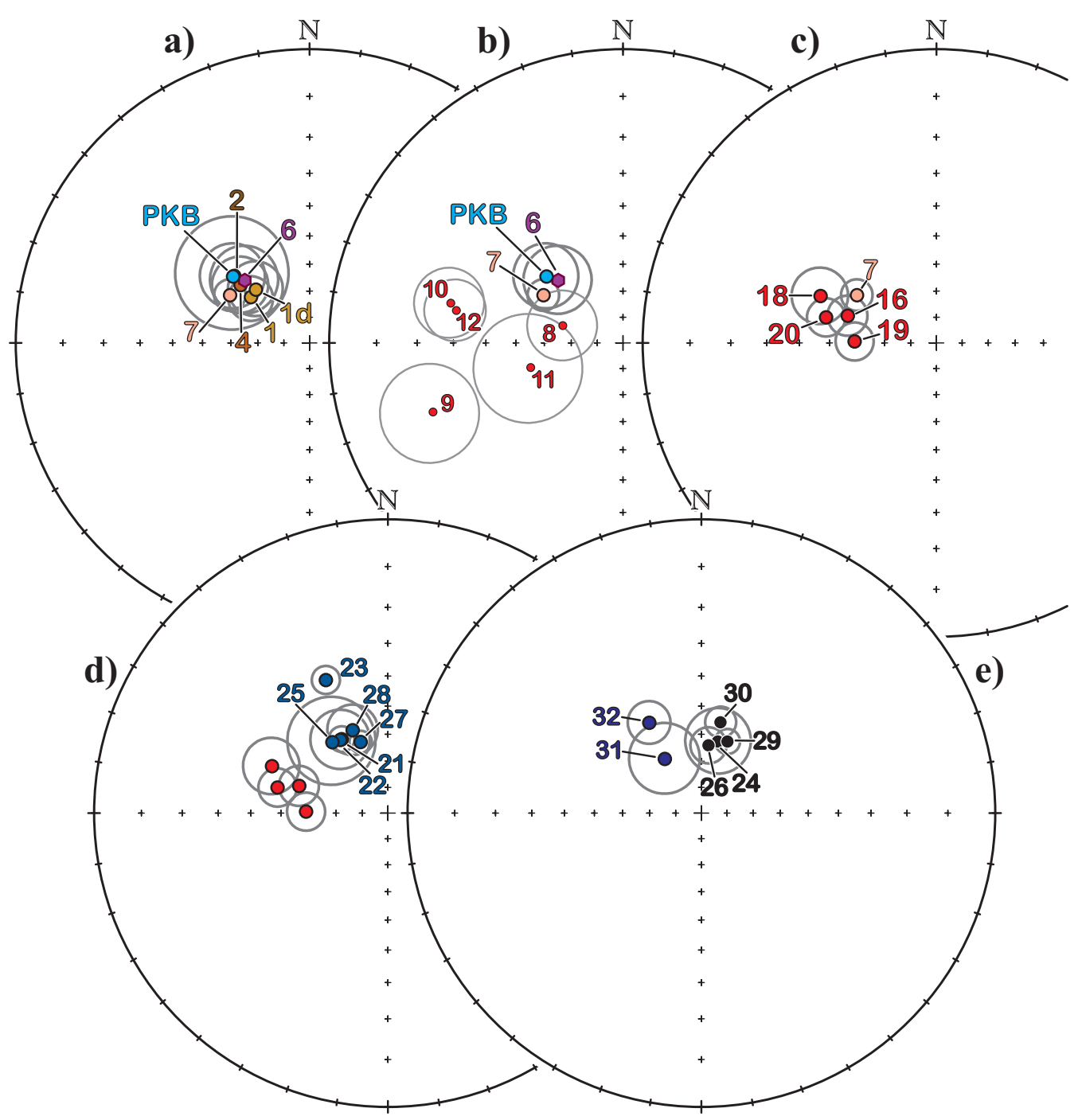


Fig. 8.
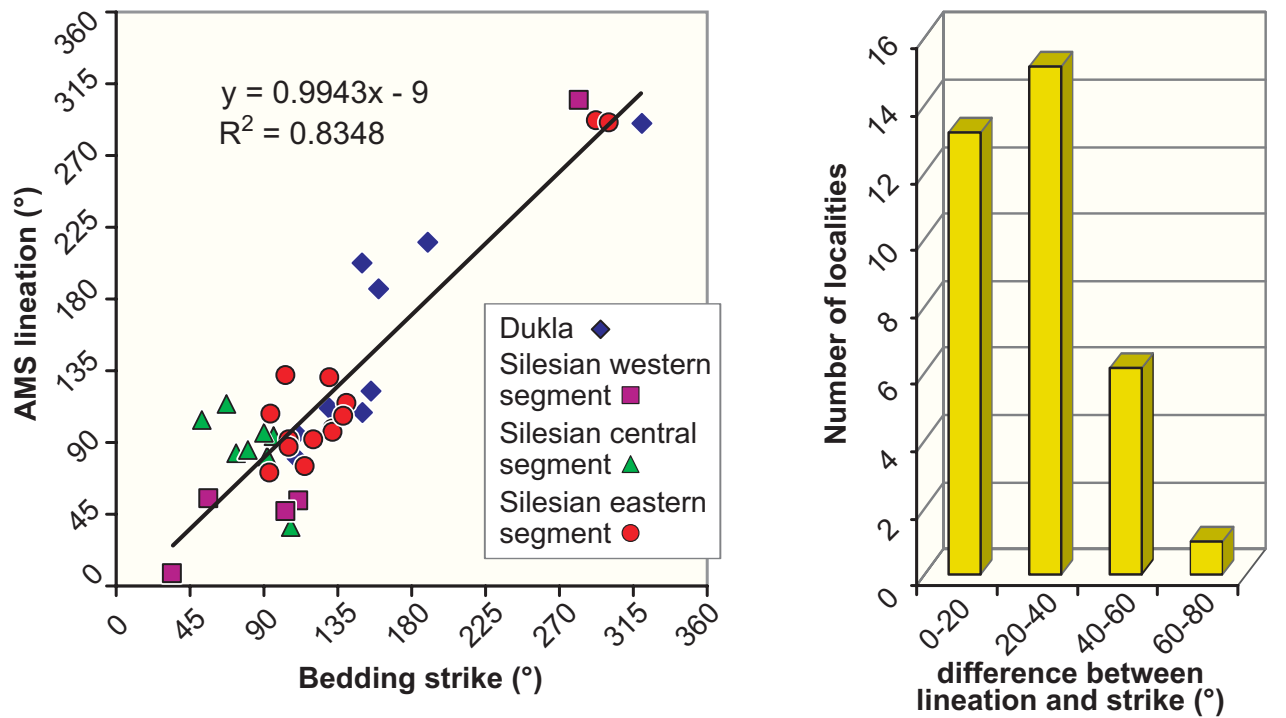
Fig. 9.

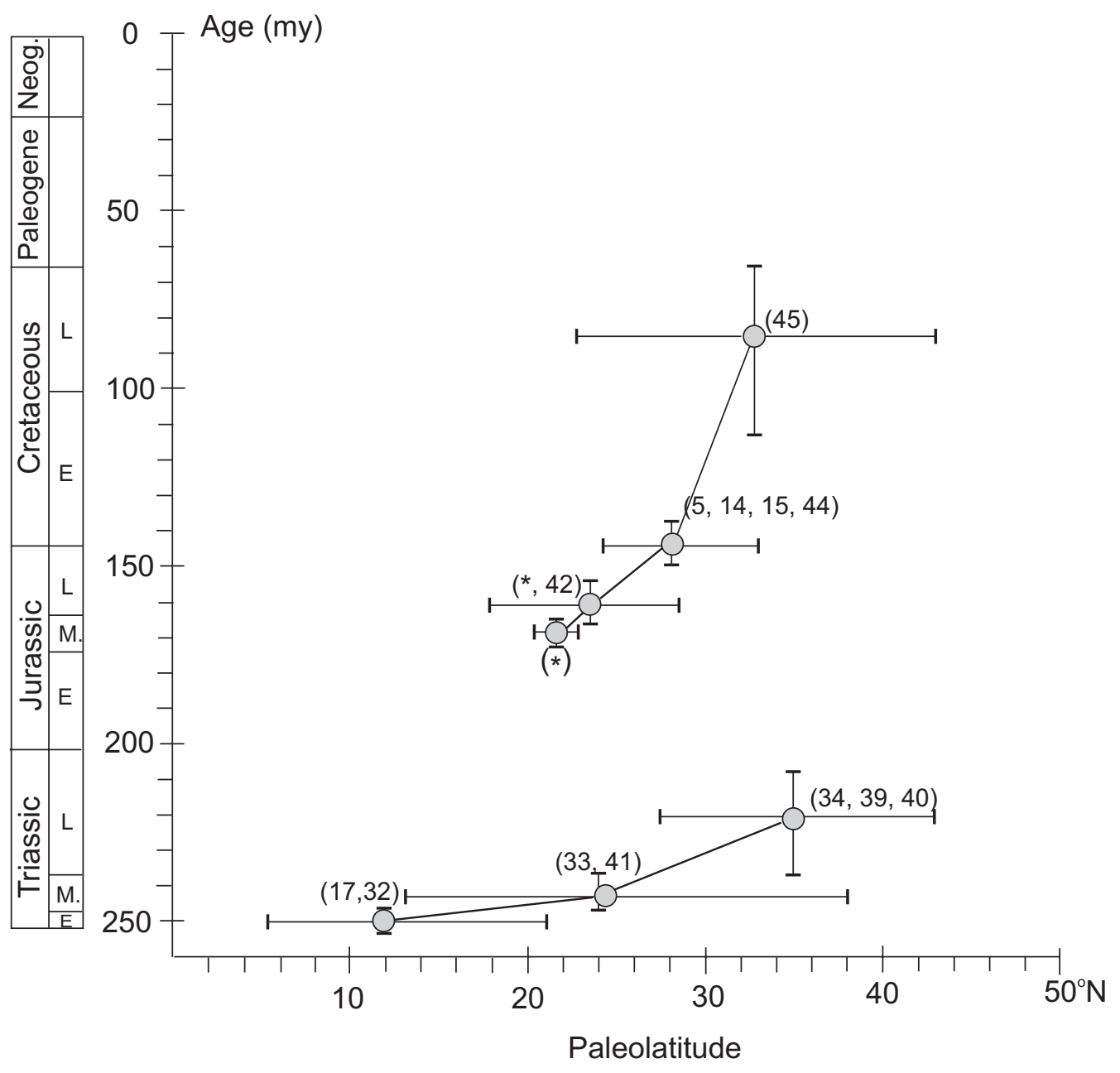




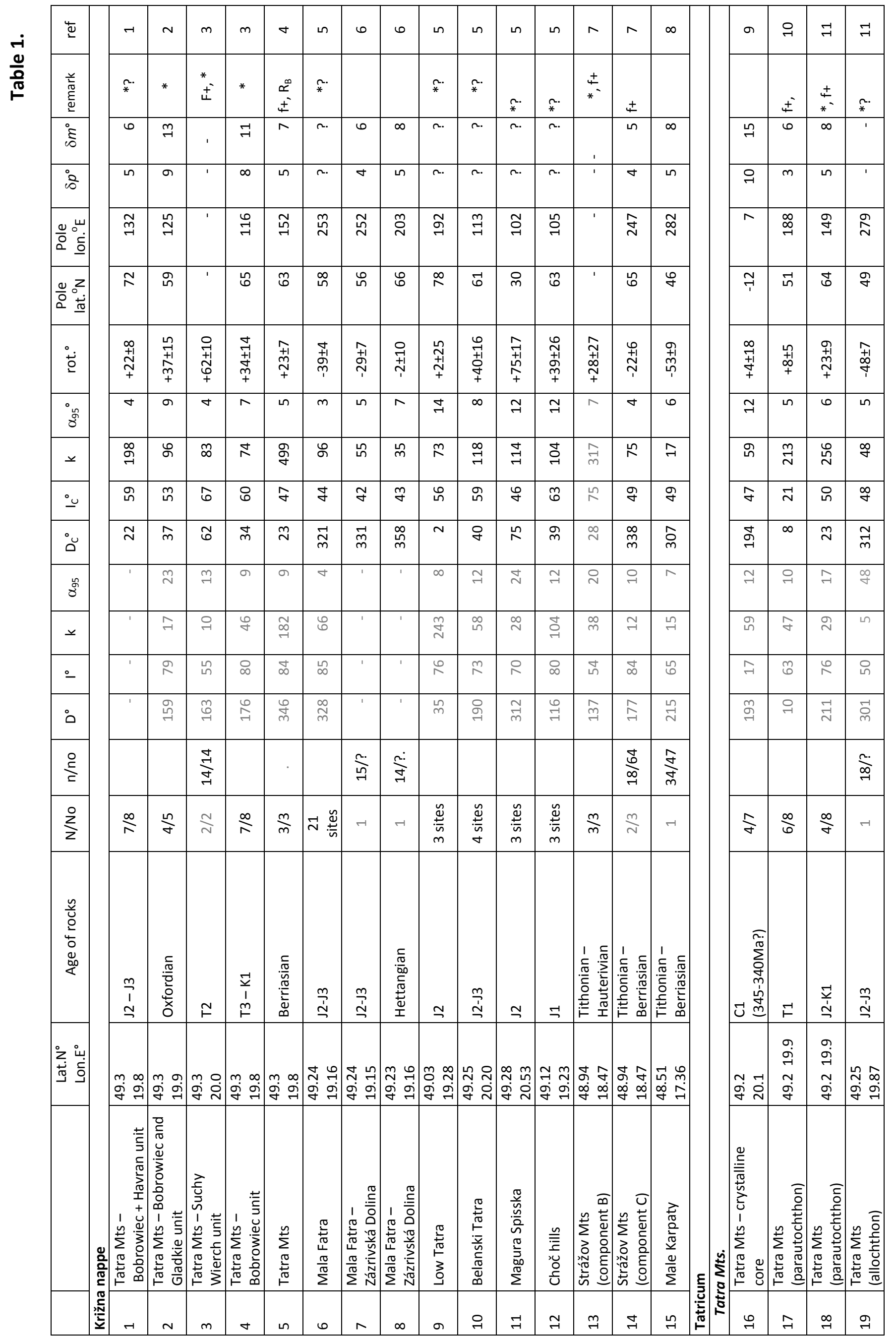




\begin{tabular}{|c|c|c|c|c|c|c|c|c|c|c|c|c|c|c|c|c|c|c|c|c|c|c|c|c|c|c|}
\hline$\vec{\sigma}$ & & 6 & 6 & & $\approx$ & $\stackrel{\eta}{\neg}$ & $\stackrel{m}{\rightarrow}$ & $\stackrel{m}{\neg}$ & 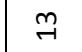 & $m$ & & 0 & 0 & & $\approx$ & & \pm : & $\%$ & 4 & & êt & $\underset{\sim}{\omega}$ & ने & F & $\stackrel{\sim}{\neg}$ & $\underset{A}{ }$ \\
\hline$\stackrel{\sim *}{*}$ & & & & & & & & & & $*$ & & & & & & & \pm & 5 & 上 & & 葛离 & & & \pm & & \pm \\
\hline I & & $\sigma$ & ᄀ & & $r$ & ન & 억 & $\stackrel{\overbrace{}}{\rightarrow}$ & $\approx$ & & & $r$ & 우 & & $m$ & & S. & at & & & 1 & ' & $\exists$ & $r$ & ' & $\vec{N}$ \\
\hline ' & & 6 & $\exists$ & & $m$ & $\sigma$ & in & $\sigma$ & 6 & ' & & n & 6 & & in & & $n$ & & & & 1 & ' & $\infty$ & $\sigma$ & ' & $m$ \\
\hline$\underset{m}{m}$ & & $\stackrel{\stackrel{\circ}{N}}{\text { r }}$ & $\stackrel{\Delta}{\sim}$ & & నे & 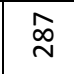 & 今ે & $\stackrel{\stackrel{\sim}{m}}{m}$ & ষ্ল & 오 & & ஸ̃ & 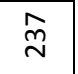 & & 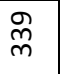 & & $\begin{array}{l}n \\
0\end{array}$ & 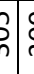 & 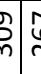 & & $\stackrel{n}{\sim}$ & $\stackrel{\infty}{m}$ & 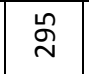 & $\stackrel{\Delta}{\sim}$ & $\stackrel{\mathscr{\infty}}{\sim}$ & $\left|\begin{array}{c}\infty \\
\sim \\
\sim\end{array}\right|$ \\
\hline$\hat{\curvearrowright}$ & & రి & in & & 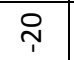 & $r$ & 7 & $\stackrel{\varphi n}{\eta}$ & ᄀ) & $\stackrel{d}{d}$ & & $\tilde{6}$ & นิ & & q & & $\sqrt{3}:$ & $\begin{array}{l}0 . \\
\text { to }\end{array}$ & t. & & 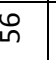 & $\vec{\gamma}$ & 8 & in & in & $\hat{m}$ \\
\hline 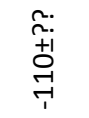 & & 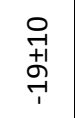 & $\begin{array}{l}\stackrel{9}{+} \\
+1 \\
⿱ 亠 䒑 \\
1\end{array}$ & & c. & n. & $\curvearrowright$ & n. & r. & $\begin{array}{l}0 \\
+ \\
+1 \\
0 \\
+ \\
+\end{array}$ & & 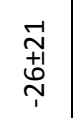 & $\begin{array}{l}\overrightarrow{7} \\
\stackrel{+1}{+} \\
\stackrel{7}{1}\end{array}$ & & 慹 & & 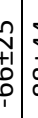 & $\begin{array}{l}f \\
\vdots \\
0 \\
0 \\
0 \\
1\end{array}$ & 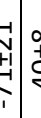 & & 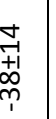 & 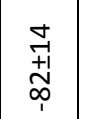 & 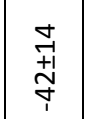 & $\stackrel{+}{+}$ & 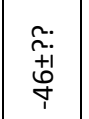 & $\left|\begin{array}{l}n \\
\multirow{1}{*}{} \\
\vdots \\
1\end{array}\right|$ \\
\hline 1 & & 6 & $\stackrel{m}{r}$ & & 6 & ब & 욱 & $\stackrel{\infty}{\sim}$ & 7 & $\infty$ & & 弯 & $\infty$ & & in & & v) & 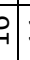 & $\exists$ & & $\bar{\sigma}$ & $n$ & $\infty$ & n & 1 & $\exists$ \\
\hline ' & & ్ㅛ & $\stackrel{\Rightarrow}{\Rightarrow}$ & & $\nabla$ & $\stackrel{m}{\neg}$ & $\infty$ & in & 6 & இ & & กี & $\underset{\sim}{\Delta}$ & & in & & $n$ & fo & oy & & 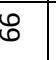 & ㄱ & $\stackrel{\infty}{+}$ & $\underset{\neg}{\stackrel{7}{7}}$ & ' & $\stackrel{i}{N}$ \\
\hline ర్రి & & मे & $\stackrel{\infty}{+}$ & & D & $\uparrow$ & $\stackrel{\infty}{\rightarrow}$ & $\stackrel{m}{\rightarrow}$ & $\underset{1}{7}$ & 8 & & $\stackrel{\infty}{+}$ & $q$ & & ન & & \pm & t & $n=$ & & 유 & นิ & \% & $\mathscr{q}$ & 只 & $\stackrel{m}{\sigma}$ \\
\hline$\stackrel{\infty}{\rightarrow-1}$ & & $\overrightarrow{\mathrm{f}}$ & $\stackrel{\omega}{m}$ & & $\approx$ & $\underset{\sim}{\stackrel{\circ}{~}}$ & $\stackrel{\stackrel{\sim}{\sim}}{\sim}$ & $\stackrel{\sim}{\sim}$ & $\stackrel{\stackrel{\circ}{N}}{ }$ & : & & $\stackrel{\text { m }}{\text { m }}$ & $\stackrel{m}{m}$ & & શิ & & 苞 & v & 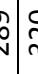 & & $\underset{\mathrm{N}}{\mathbb{N}}$ & ஓ & $\begin{array}{l}\stackrel{0}{m} \\
m\end{array}$ & $\begin{array}{l}\stackrel{0}{m} \\
\vec{m}\end{array}$ & $\underset{m}{\vec{m}}$ & $\stackrel{\infty}{\stackrel{\infty}{N}}$ \\
\hline ' & & ' & ' & & ' & ᄀ & 의 & ㅇ & 의 & $\Lambda$ & & ' & ' & & 1 & & g & $\Leftrightarrow$ & 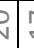 & & $\stackrel{1}{\sigma}$ & n & N & $\infty$ & I & 감 \\
\hline ' & & & 1 & & ' & $\stackrel{m}{\sim}$ & $\infty$ & $\nabla$ & $r$ & g) & & ' & ' & & & & - & . & & & స & ㄱ & ఫ & of & ' & 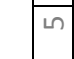 \\
\hline بo & & 1 & 1 & & 1 & ᄀ & $\stackrel{\vec{\gamma}}{\top}$ & $\stackrel{\sim}{\sim}$ & $\vec{T}$ & $\stackrel{\infty}{m}$ & & 1 & ' & & 1 & & ก & 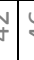 & 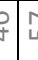 & & 유 & ○్రి & $\overrightarrow{6}$ & ర్ర & Z & $N$ \\
\hline P & & & ' & & ' & $\stackrel{\sim}{\stackrel{0}{N}}$ & $\stackrel{\infty}{\stackrel{\infty}{\sim}}$ & $\stackrel{\sim}{\sim}$ & $\underset{\sim}{\sim}$ & $\underset{ন}{J}$ & & ' & 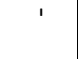 & & & & S & S & g & & $\begin{array}{l}\infty \\
\text { m }\end{array}$ & $\stackrel{\infty}{\circ}$ & $\stackrel{\infty}{\stackrel{\infty}{m}}$ & $\stackrel{\vec{m}}{\text { m }}$ & $\stackrel{\infty}{\infty}$ & $m$ \\
\hline$\stackrel{\substack{\infty \\
\sim}}{\sim}$ & & 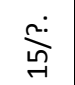 & 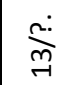 & & & & & & & $\stackrel{n}{n}$ & & $\stackrel{\text { : }}{\underset{J}{J}}$ & $\frac{\stackrel{n}{*}}{\stackrel{N}{*}}$ & & & & & & & & & $\frac{2}{8}$ & & & & \\
\hline$\stackrel{\circ}{\stackrel{9}{v}}$ & & -1 & $\rightarrow$ & & 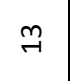 & 0 & $m$ & $\stackrel{0}{1}$ & $\tilde{m}$ & -1 & & $r$ & - & & $\sigma$ & & $n$ & f & 0 & & $\frac{0}{i n}$ & $\stackrel{0}{-}$ & $\infty$ & $\infty$ & $\stackrel{\infty}{\sim}$ & in \\
\hline$\stackrel{\vec{r}}{\dot{m}}$ & & 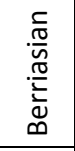 & 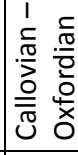 & & a & a & a & a & a & $F$ & & 亮 & 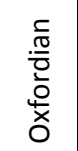 & & 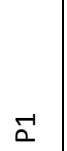 & & $\begin{array}{l}-1 \\
\end{array}$ & 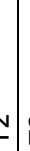 & $f F$ & & $\frac{\frac{1}{i}}{v}$ & $\stackrel{m}{\sim}$ & $\stackrel{m}{p}$ & $\stackrel{m}{p}$ & 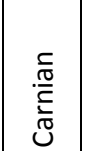 & $F$ \\
\hline $\begin{array}{l}\text { gे } \\
\text { ने } \\
\sim \\
\dot{\sigma}\end{array}$ & & 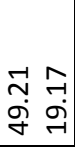 & $\begin{array}{ll}\hat{\sigma} & 8 \\
\infty & 0 \\
\dot{\sigma} & 9\end{array}$ & & 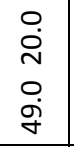 & 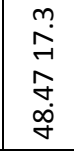 & 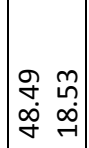 & 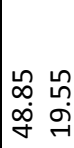 & 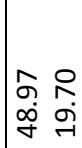 & $\begin{array}{l}\text { ஸे } \\
\dot{g} \\
g \\
g\end{array}$ & & 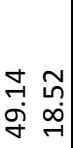 & 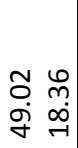 & & 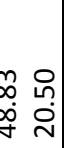 & & & & $\begin{array}{l}a \\
\vdots \\
\vdots \\
\vdots \\
a\end{array}$ & & 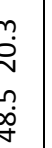 & $\begin{array}{l}m \\
\stackrel{n}{ } \\
i n \\
\infty \\
\infty \\
q\end{array}$ & 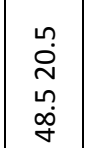 & 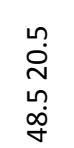 & $\begin{array}{l}\stackrel{-}{0} \\
\text { 1 } \\
\infty \\
\infty \\
\dot{q}\end{array}$ & \\
\hline 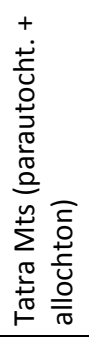 & $\begin{array}{l}0 \\
0 \\
0 \\
0 \\
0 \\
0 \\
0 \\
0 \\
0 \\
0 \\
0 \\
0\end{array}$ & 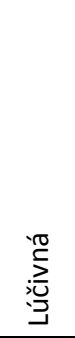 & 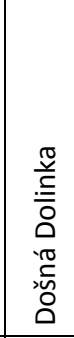 & : & 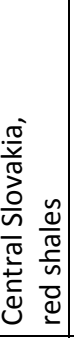 & 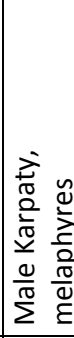 & 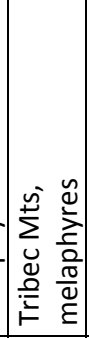 & 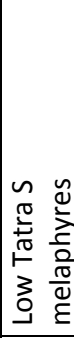 & 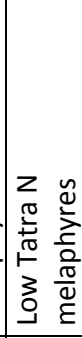 & 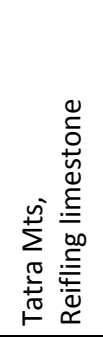 & 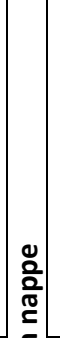 & 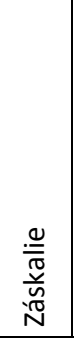 & $\begin{array}{l}\text { 总 } \\
\text { 产 }\end{array}$ & & 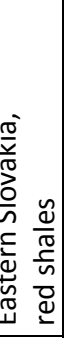 & & 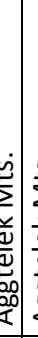 & & 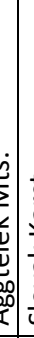 & & 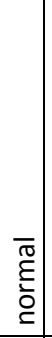 & 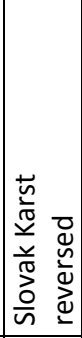 & 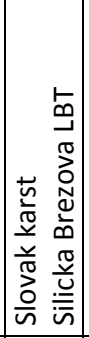 & 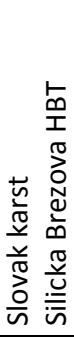 & 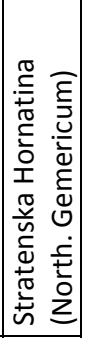 & 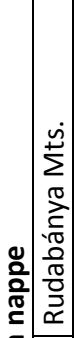 \\
\hline ㅇ & $\sum^{0}$ & $\vec{N}$ & N & $\begin{array}{l}\text { ठ̀) } \\
\text { ù }\end{array}$ & $\stackrel{\sim}{\sim}$ & $\stackrel{d}{\sim}$ & $\stackrel{\llcorner}{\sim}$ & $\stackrel{\mathscr{N}}{2}$ & 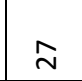 & $\stackrel{\infty}{\sim}$ & 䎡 & ని & ஓ & | & $\vec{m}$ & ֶֶ. & val & n & 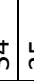 & & $\stackrel{2}{n}$ & $\hat{m}$ & $\stackrel{\infty}{m}$ & ले & q & 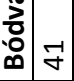 \\
\hline
\end{tabular}




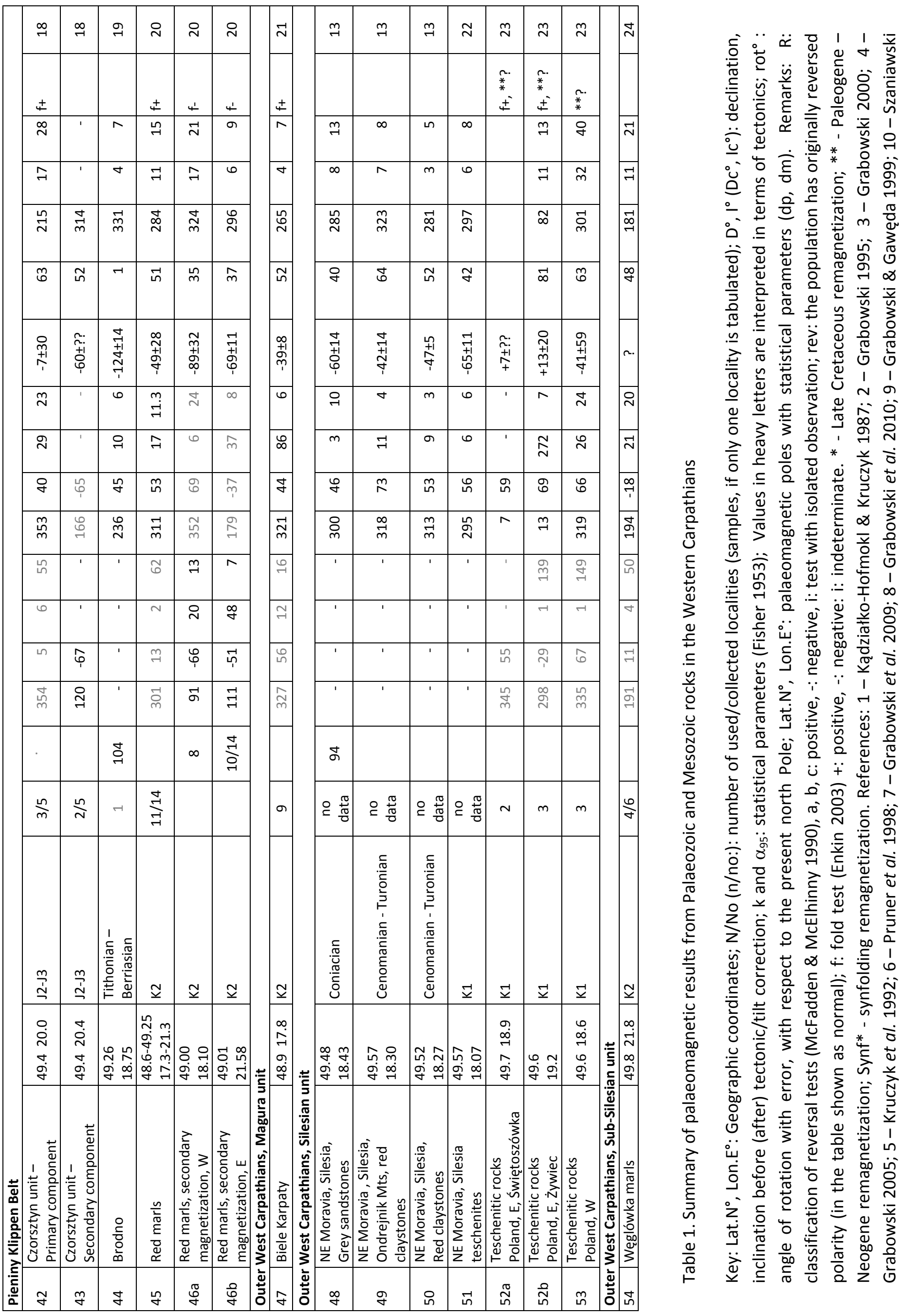


ᄀ

ò

न

क

t)

둔

ปั

1

늠

的

응

ธ่

$+\infty$

든

$\sum^{-\pi} \approx$

$\dot{m}$

욤

$\ddot{\infty} \overline{0}$

ดี เே

व் 늠

d

ᄃ

总

$1 \dot{0}$

$\underset{\sim}{\triangle}$

iิ

곤

के

๘

产

1 S

m

भิष

궁

亲

$\infty$ 궁

๖ั

苛

$1 \pm$

금

กิ

बำ

可

$\sum_{0} 1 \frac{m}{\circ}$

힘

1 유 ๘

光的

겅

으 $\overline{\bar{d}}$

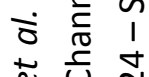




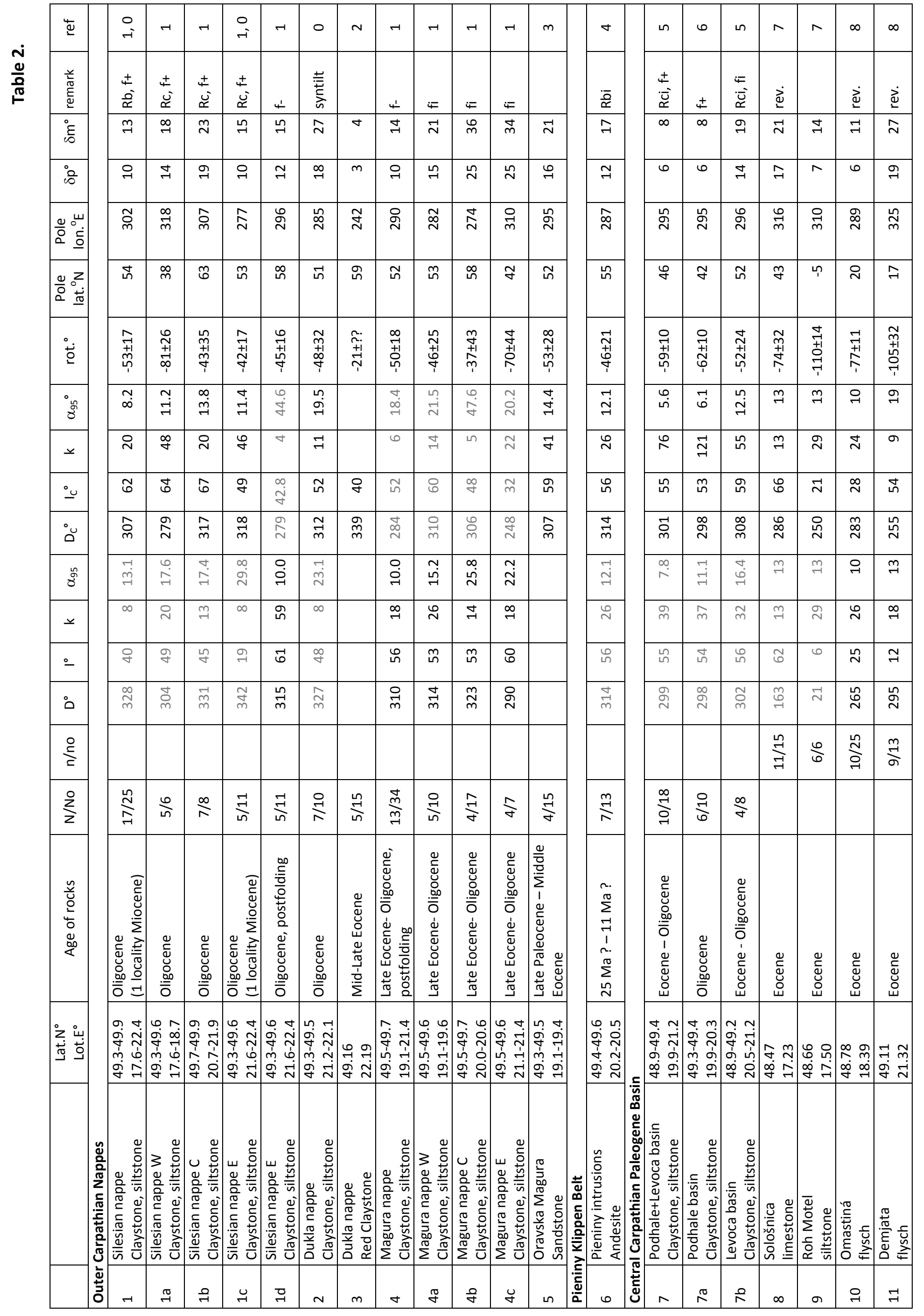




\begin{tabular}{|c|c|c|c|c|c|c|c|c|c|c|c|c|c|c|c|c|c|c|c|c|}
\hline$\sigma$ & & r & n & n & 욱 & 우 & ન & 겅ㅇ & $\stackrel{9}{\sim} \underset{\sim}{\sim}$ & $\stackrel{\neg}{\neg}$ & 우 & 욱 & $\stackrel{9}{\rightarrow} \stackrel{\sim}{\sim}$ & 우 & $\stackrel{m}{\rightarrow}$ & $m$ & $\stackrel{m}{\rightarrow}$ & $\stackrel{n}{\sim}$ & 욱 & 웅 \\
\hline & & ஹं & & & ஹं & $\begin{array}{l}\overline{\bar{\alpha}} \\
\propto \\
\dot{4}\end{array}$ & $\begin{array}{l}\breve{q} \\
\dot{F}\end{array}$ & ஹं & ஹं & $\frac{0}{\alpha}$ & i & 웃 & $\overline{\mathscr{y}}$ & ऐं & & ஹं & $\dot{\grave{u}}$ & ஹ் & & ญे \\
\hline 우 & & $\approx$ & $\sigma$ & ㄱ & 욱 & $\vec{m}$ & $\exists$ & $\stackrel{m}{r}$ & $\infty$ & $r$ & ก & in & 9 & $\sigma$ & $\stackrel{J}{\sim}$ & $\sigma$ & $r$ & 욱 & $\exists$ & $\approx$ \\
\hline 6 & & $r$ & 6 & $\infty$ & $r$ & $\bar{N}$ & $r$ & 우 & 6 & in & 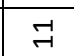 & $m$ & J & $m$ & $\stackrel{\varphi}{\sim}$ & $m$ & 6 & $\infty$ & 6 & $\underset{-1}{0}$ \\
\hline ఫ్ & & $\stackrel{+}{\sim}$ & $\stackrel{\infty}{\sim}$ & నิ & $\stackrel{\text { L }}{\text { n }}$ & $\stackrel{m}{m}$ & $\stackrel{\infty}{\sim}$ & $\stackrel{\infty}{m}$ & ర్లి & $\stackrel{\curvearrowright}{\sim}$ & 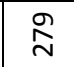 & $\stackrel{\mathscr{I}}{N}$ & $\stackrel{m}{\rightarrow}$ & $\stackrel{\infty}{\stackrel{\infty}{二}}$ & 狊 & nn & $r$ & $\underset{7}{0}$ & 곡 & $\stackrel{-\infty}{N}$ \\
\hline 9 & & ని & in & $\hat{m}$ & $\ddot{m}$ & กิ & $\stackrel{\infty}{m}$ & $\stackrel{\Perp}{\sim}$ & m & ఫु & ఫ & 号 & $\infty$ & $N$ & 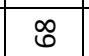 & $\stackrel{m}{n}$ & 2 & $\infty$ & $n$ & 8 \\
\hline $\begin{array}{l}0 \\
\text { †1 } \\
\text { +1 } \\
1\end{array}$ & & $\begin{array}{l}n \\
+1 \\
+1 \\
0 \\
1\end{array}$ & $\begin{array}{l}\underset{7}{7} \\
\text { 孛 } \\
i\end{array}$ & 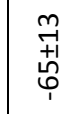 & $\underset{\substack{n \\
+1 \\
\stackrel{n}{n}}}{1}$ & 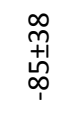 & \begin{tabular}{l}
7 \\
\multirow{0}{*}{} \\
0 \\
1
\end{tabular} & 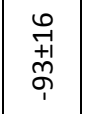 & 足 & $\begin{array}{l}\infty \\
\stackrel{\infty}{+} \\
\stackrel{m}{1}\end{array}$ & $\begin{array}{l}\stackrel{9}{7} \\
+1 \\
0 \\
1\end{array}$ & $\begin{array}{l}\stackrel{n}{+} \\
\stackrel{+}{N} \\
\end{array}$ & $\begin{array}{l}\stackrel{0}{1} \\
+1 \\
\stackrel{m}{+} \\
+\end{array}$ & 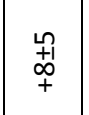 & $\begin{array}{l}\underset{\infty}{+} \\
+1 \\
\infty \\
+ \\
+\end{array}$ & $\begin{array}{l}\stackrel{0}{1} \\
\stackrel{1}{\sim} \\
+\end{array}$ & 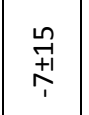 & $\begin{array}{l}\underset{+}{+} \\
\underset{+}{+} \\
+\end{array}$ & 壳 & 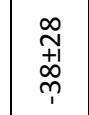 \\
\hline$\sigma$ & & $\exists$ & r & $\sigma$ & $\vec{r}$ & 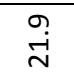 & $\begin{array}{l}n \\
\infty\end{array}$ & ०ें & นึ & $\underset{+}{\mathscr{\sigma}}$ & $\begin{array}{l}0 \\
0 \\
0\end{array}$ & $\stackrel{\text { f }}{+}$ & $\underset{7}{\stackrel{9}{7}}$ & $\stackrel{m}{m}$ & $\stackrel{\infty}{\sim}$ & $\vec{i}$ & $\stackrel{\infty}{\dot{m}}$ & 0 & $\begin{array}{l}\circ \\
\stackrel{\leftrightarrow}{\circ}\end{array}$ & $\begin{array}{l}\dot{\varphi} \\
\stackrel{\sim}{\sim}\end{array}$ \\
\hline$\exists$ & & $\stackrel{4}{4}$ & \& & $\stackrel{n}{N}$ & $\widetilde{6}$ & $\stackrel{m}{m}$ & F & $\stackrel{m}{m}$ & 도 & R & $\dddot{2}$ & q & ร & สี & ঃ & $\stackrel{n}{n}$ & $\stackrel{ }{\text { ㄱ. }}$ & ถั & $m$ & 9 \\
\hline m & & $m$ & g & $\stackrel{\infty}{\neg}$ & 缉 & 员 & q & in & $\stackrel{\infty}{\sim}$ & in & n̂ & $\widehat{m}$ & $\widetilde{\sigma}$ & in & in & 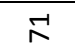 & $\stackrel{n}{\wedge}$ & ఫ & $\stackrel{\sim}{\sim}$ & மீ \\
\hline$\stackrel{\infty}{\sim}$ & & ֻু & $\stackrel{\stackrel{n}{m}}{m}$ & 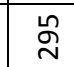 & $\stackrel{\infty}{N}$ & 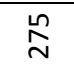 & ষ্ল & $\hat{\imath}$ & $\stackrel{\infty}{\sim}$ & $\stackrel{\infty}{m}$ & 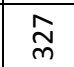 & $\stackrel{\sim}{m}$ & $m$ & $\infty$ & $\stackrel{\infty}{\sim}$ & $\stackrel{\Perp}{N}$ & $\stackrel{m}{m}$ & $\stackrel{\sim}{\sim}$ & 芦 & $\underset{\sim}{\tilde{m}}$ \\
\hline$\sigma$ & & $\exists$ & r & $\exists$ & $\stackrel{7}{i}$ & $\begin{array}{l}\underset{\sim}{\tilde{N}} \\
\text { D. }\end{array}$ & $m$ & Oें & นึ & $\stackrel{\varphi}{\dot{r}}$ & बे & $\stackrel{+}{+}$ & $\begin{array}{l}\stackrel{\rightarrow}{\rightarrow} \\
\overrightarrow{-}\end{array}$ & $\stackrel{m}{m}$ & $\stackrel{\infty}{\sim}$ & $\vec{i}$ & $\stackrel{\infty}{m}$ & 6 & $\begin{array}{l}0 \\
\text { ○े }\end{array}$ & $\begin{array}{l}\text { ம் } \\
\stackrel{\leftrightarrow}{n}\end{array}$ \\
\hline J & & $\stackrel{\text { N }}{ }$ & \& & $\stackrel{\forall}{\forall}$ & $\widetilde{\sigma}$ & $\stackrel{\infty}{\sim}$ & $\hat{m}$ & $m$ & ก & ㅇ & ஜ & q & テ & สู & & $\stackrel{\sim}{n}$ & 엄 & 苞 & $m$ & 9 \\
\hline in & & q & $\stackrel{\infty}{m}$ & กn & นก & m & ஜ & in & $\stackrel{\infty}{+}$ & ถิ & น & $\hat{m}$ & $\widetilde{\sigma}$ & ㅇํ & 요 & 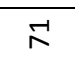 & $\stackrel{n}{n}$ & ఫే & $\stackrel{m}{\sim}$ & in \\
\hline$\stackrel{\mathbb{D}}{\sim}$ & & 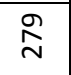 & 而 & लี & $\stackrel{\infty}{\sim}$ & ֻั & $\stackrel{m}{m}$ & $\stackrel{\hat{Q}}{N}$ & $\stackrel{\infty}{\sim}$ & $\stackrel{\infty}{m}$ & $\stackrel{\Xi}{m}$ & $\stackrel{\sim}{m}$ & $\stackrel{m}{\sim}$ & $\infty$ & $\stackrel{\infty}{\sim}$ & $\stackrel{\Perp}{N}$ & $\stackrel{n}{m}$ & $\stackrel{n}{\sim}$ & 岕 & $\underset{m}{\mathbb{m}}$ \\
\hline$\stackrel{\vec{\sim}}{\stackrel{\sim}{\sim}}$ & & $\stackrel{\stackrel{n}{\sim}}{\sigma}$ & $\stackrel{0}{\stackrel{1}{0}}$ & 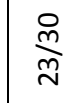 & & & & & & & & & & $\underset{\underset{\sim}{\sim}}{\stackrel{\sim}{ה}}$ & $\frac{0}{n}$ & 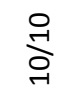 & $\frac{a}{\infty}$ & 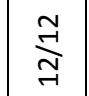 & $\stackrel{\varrho}{\infty}$ & \\
\hline & & & & & $\underset{\infty}{\stackrel{0}{1}}$ & $\frac{m}{m}$ & $\stackrel{\sigma}{\infty}$ & $\frac{\sigma}{\sigma}$ & $\underset{\vec{F}}{\vec{I}}$ & $\stackrel{\stackrel{n}{\sim}}{\stackrel{\overbrace{}}{\sim}}$ & $\stackrel{\partial}{\partial}$ & 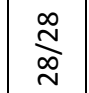 & $\frac{0}{n}$ & & & & & & & $\hat{\theta}$ \\
\hline $\begin{array}{l}\sum_{\infty}^{\infty} \\
\stackrel{1}{1} \\
\stackrel{N}{N}\end{array}$ & & 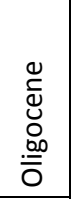 & 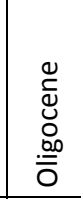 & 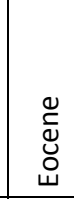 & 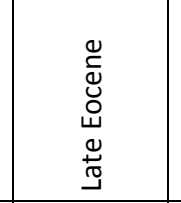 & 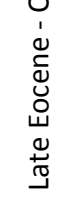 & $\begin{array}{l}\sum_{0}^{\pi} \\
0 \\
\infty \\
-1 \\
0 \\
0 \\
0\end{array}$ & 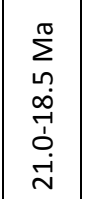 & $\begin{array}{l}\sum_{10}^{\pi} \\
\infty \\
\infty \\
\vdots \\
0 \\
-1 \\
-i\end{array}$ & 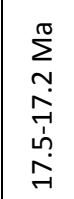 & $\begin{array}{l}\sum_{0}^{\pi} \\
0 \\
m \\
\rightarrow \\
0 \\
\infty \\
\infty \\
-1\end{array}$ & 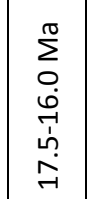 & $\begin{array}{l}\sum_{0}^{\pi} \\
0 \\
\ddot{M} \\
\ddot{1} \\
\dot{j} \\
\dot{J}\end{array}$ & $\begin{array}{l}\sum_{0}^{\pi} \\
0 \\
\dot{J} \\
-1\end{array}$ & $\begin{array}{l}\sum_{0}^{\pi} \\
0 \\
\dot{+} \\
\stackrel{1}{1} \\
\stackrel{M}{r}\end{array}$ & 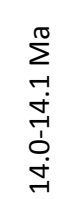 & 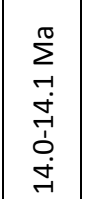 & $\begin{array}{l}\sum_{0}^{\pi} \\
\sigma \\
\ddot{n} \\
\ddot{1} \\
\ddot{n} \\
\end{array}$ & 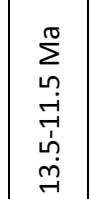 & 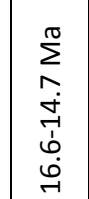 \\
\hline 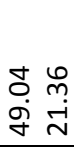 & 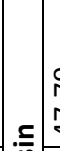 & 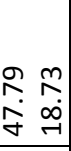 & 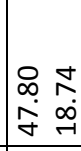 & 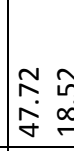 & 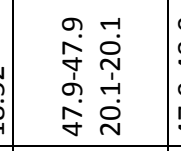 & 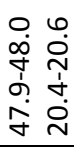 & 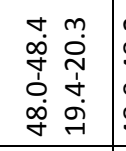 & 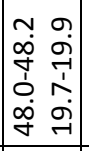 & 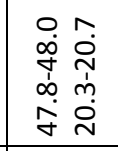 & 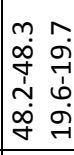 & 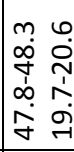 & 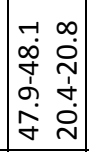 & 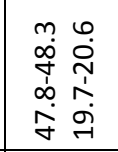 & 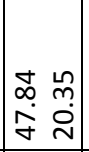 & 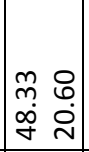 & 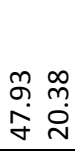 & $\begin{array}{ll}m & 0 \\
o & m \\
\dot{f} & \stackrel{d}{\sim}\end{array}$ & 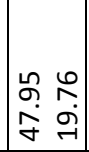 & 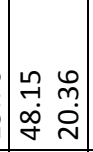 & 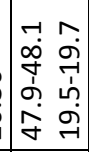 \\
\hline 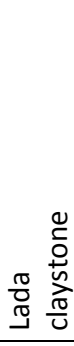 & 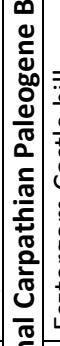 & 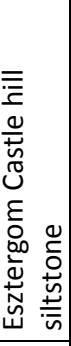 & 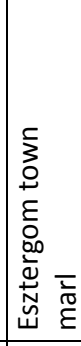 & 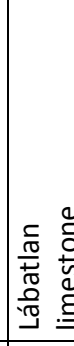 & 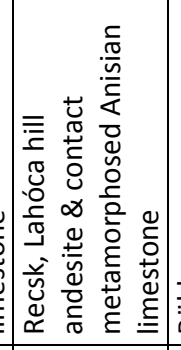 & 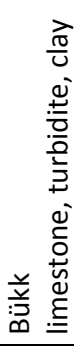 & 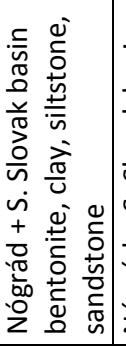 & 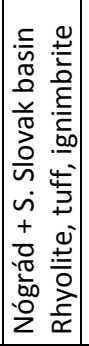 & 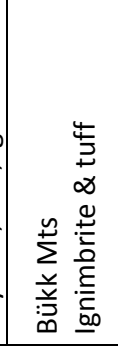 & 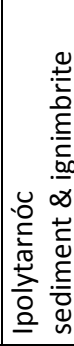 & 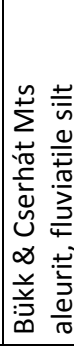 & 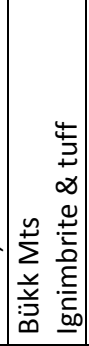 & 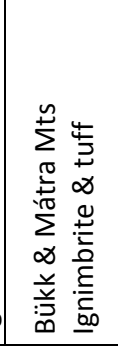 & 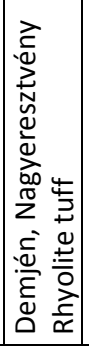 & 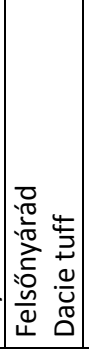 & 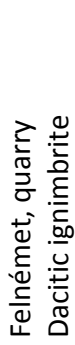 & 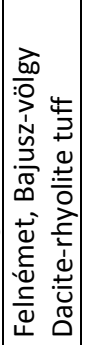 & 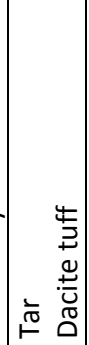 & 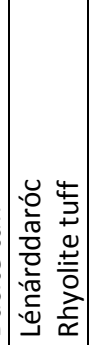 & 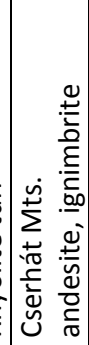 \\
\hline$\underset{7}{*}$ & $\mid$\begin{tabular}{|l} 
\\
$\overline{\mathbf{v}}$ \\
$\underline{\underline{\Xi}}$
\end{tabular} & $\stackrel{m}{\rightarrow}$ & $\underset{-}{A}$ & $\stackrel{\sim}{\sim}$ & $\stackrel{\bullet}{\oplus}$ & $\exists$ & $\stackrel{\infty}{\rightarrow}$ & ન & ㅇ & $\vec{N}$ & $\approx$ & $\stackrel{\sim}{\sim}$ & $\stackrel{ \pm}{\sim}$ & $\stackrel{\mathbb{J}}{\sim}$ & $\stackrel{?}{\sim}$ & $\stackrel{\text { I }}{\text { I }}$ & 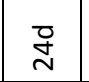 & $\stackrel{g}{\sim}$ & $\stackrel{+}{\sim}$ & $\stackrel{\sim}{\sim}$ \\
\hline
\end{tabular}




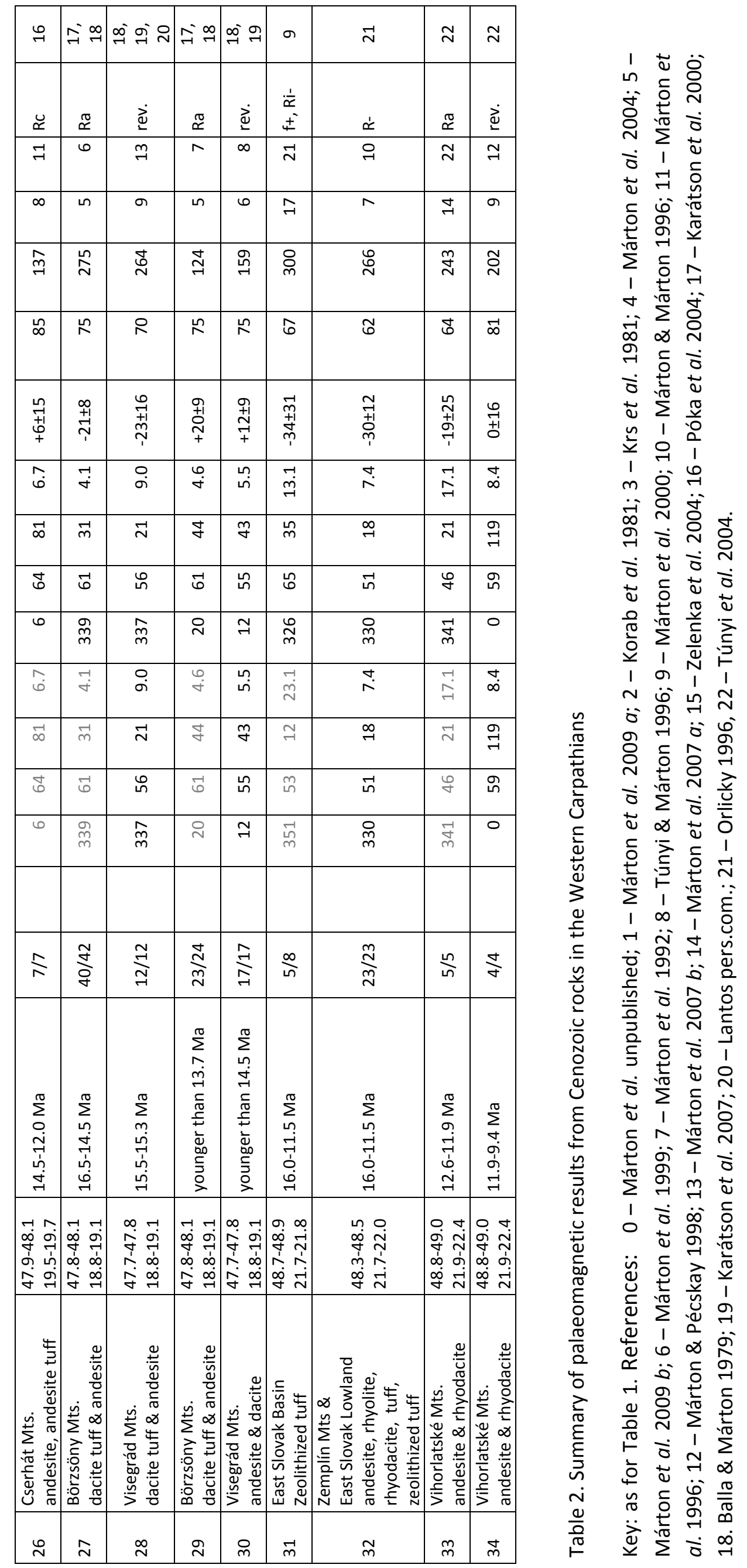

